\title{
Review
}

\section{Impact of several common tree species of European temperate forests on soil fertility}

\author{
Laurent Augusto ${ }^{\mathrm{a}}$ Jacques Ranger ${ }^{\mathrm{a},{ }^{*}}$, Dan Binkley ${ }^{\mathrm{b}}$ and Andreas Rothe ${ }^{\mathrm{c}}$ \\ ${ }^{a}$ Institut National de la Recherche Agronomique, 54280 Champenoux, France \\ ${ }^{\mathrm{b}}$ Department of Forest Sciences, Graduate Degree Program in Ecology, and Natural Resource Ecology Laboratory, \\ Colorado State University, Fort Collins, Colorado, 80523, USA \\ c Bayerisches Staatsministerium für Landwirtschaft und Forsten, Referat Waldbau und Nachhaltssicherung, Ludwigstraße 2, \\ 80539 München, Germany
}

(Received 3 April 2001; accepted 28 September 2001)

\begin{abstract}
The aim of the present work was to provide a synopsis of the scientific literature concerning the effects of different tree species on soil and to quantify the effect of common European temperate forest species on soil fertility. The scientific literature dealing with the tree species effect on soil has been reviewed. The composition of forest overstory has an impact on the chemical, physical and biological characteristics of soil. This impact was highest in the topsoil. Different tree species had significantly different effects on water balance and microclimate. The physical characteristics of soils also were modified depending on the overstory species, probably through modifications of the soil fauna. The rates of organic matter mineralization and nitrification seem to be dependent on tree species. A coniferous species, Picea abies, had negative input-output budgets for some nutrients, such as $\mathrm{Ca}$ and $\mathrm{Mg}$. This species promoted a higher soil acidification and a decrease in $\mathrm{pH}$. Thus, it should not be planted in very poor soils in areas affected by acidic atmospheric depositions. Nevertheless, the effect of the canopy species on soil fertility was rarely significant enough to promote forest decline. The impact of a tree species on soil fertility varied depending on the type of bedrock, climate and forest management.
\end{abstract}

\section{forest soils / tree species / fertility / sustainability / resiliency}

Résumé - Effet des principales essences des forêts tempérées sur la fertilité des sols. L'objectif de cet article est de fournir une synthèse bibliographique au sujet de l'effet des essences sur le sol, et, en particulier, de l'effet des principales essences utilisées en foresterie tempérée. La composition du couvert arboré a une influence importante sur les propriétés physiques, chimiques et biologiques du sol. Cet impact est le plus important dans les horizons superficiels. L'effet des essences se traduit au niveau du pédoclimat, modifiant fortement le bilan hydrique du sol. La modification des paramètres physiques est liée à l'activité biologique, elle même dépendant de nombreux paramètres chimiques et biochimiques. La dégradation de la matière organique (minéralisation) et la nitrification semblent dépendre des essences. L'épicéa commun conduit à une acidification substantielle du sol qui se traduit parfois au niveau du pH ; les bilans d'éléments nutritifs calculés pour cette essence sont le plus souvent négatifs pour des éléments tels Ca et Mg. Cette essence ne doit pas être introduite sur des sols trop pauvres ou affectés par des apports atmosphériques acidifiants. Il faut cependant insister sur le fait que le seul effet des essences n'est jamais tel qu'il puisse conduire au dépérissement des forêts. L'impact des essences sur la fertilité du sol dépend du type de sol, du climat et des aménagements forestiers (essences et traitement).

sols forestiers / essences forestières / fertilité des sols / durabilité / résilience

\footnotetext{
* Correspondence and reprints

Tel. +33 3833940 68; Fax. +33 3833940 69; e-mail: ranger@nancy.inra.fr
} 


\section{INTRODUCTION}

\subsection{Tree species in European forests}

The development of human societies often has caused an overexploitation of forests and a decrease in their area. In Europe, the minimum of forest cover occurred during the 18th and 19th centuries [52] Since the second half of the 19th century, policies of afforestation and increasing wood production have been imposed. One major characteristic of these policies has been the planting of large areas of productive coniferous tree species. In some cases, forests of native deciduous species have been replaced by plantations of coniferous species. The extensive use of coniferous species has modified the average composition of the western European temperate forest [52, 181]. These coniferous species were sometimes translocated within Europe (for example, Norway spruce, Picea abies and Scots pine, Pinus sylvestris). Others were imported from North America (for example, Sitka spruce, Picea sitchensis and Douglas fir, Pseudotsuga menziesii). Substitutions of tree species has given rise to considerable discussions in some western European countries. These discussions led to numerous studies on the effects of overstory species composition on forest ecosystems. The existence of an overstory species effect on soils has been known for a long time (Dokuchaev, in [95]) and has been observed by many authors (e.g. $[2,33,56])$. Nevertheless, the intensity of the species effect is estimated in very different or even contradictory ways, depending on the researcher. According to Stone [196] and van Goor [209], the effect of canopy species on soil fertility is minimal compared to the effects of soil management and forest management. In contrast, in studies of peatbogs [216] and artificial soils [77, 165, 200, 203] the composition of the tree cover can be one of the major factors determining the characteristics and the long term evolution of forest soils, at least for topsoil. The discrepancies among the various results concerning the effect of the tree species are partly explained by variations between soils of some of the study sites (see comments in [31]).

The aim of the present work is to review the scientific literature concerning differences in the qualitative and quantitative impact on soil fertility by the common overstory species (often called "effect of tree species" in our study) of European temperate forests (see [31] for a review of the American tree species).

\subsection{Soil fertility concept}

Soil fertility is a rather complicated concept. It is commonly defined as the "capacity of a soil to produce a large harvest". So, it is clear that the concept of soil fertility is linked to the physical, chemical, biological, climatic and anthropic characteristics of the site. Considering the numerous studies that have been done on the effects of different tree species, it appears that the overstory composition probably does impact soil fertility. The crucial point is to determine if the nature and the intensity of the modifications caused by a tree species are sufficient to significantly decrease or increase soil fertility [32]. From a theoretical point of view, the impact of the overstory species on soil fertility is not significant as long as the processes of the ecosystem which are modified do not become limiting factors for the trees or other parts of the system. That is to say that the tree species impact on soil fertility is the result of interactions between the trees and all the components of the ecosystem, and not just the effect of the trees on mineral soil [32]. Indeed, the impact of a canopy species on soil fertility could differ substantially on different bedrocks. For instance, stands growing on acidic soils which developed from crystalline rocks poor in $\mathrm{Ca}$ and $\mathrm{Mg}$ (e.g. sandstone, sand or granite rich in $\mathrm{Si}$ ) could decline because of nutrient deficiencies [124, 146]. In such soils, planting a tree species which has a negative nutrient balance could promote a decline [70]. On the contrary, planting an acidifying tree species in shallow soils that have developed on compact limestones could increase the volume of soil exploitable by roots and thus improve soil fertility. This phenomenon has been observed with the cultivation of Pinus nigra (Bonneau, unpublished data). As the relationship between soil fertility and tree species is not unequivocal, our aim is to provide advice rather than general rules for forest management.

\section{METHOD OF REVIEW}

There are many papers dealing with the effects of different canopy species on soils. However, comparisons among tree species are very difficult because many factors should be taken into account. Most importantly, the strength of the experimental design determines the level of confidence in the study. We grouped the studies from the literature according to experiment design:

(i) studies with strong experimental designs that were carried out in stands which were replicated, of the same age, managed in the same way, and growing on the same 
soil type (and thus on the same bedrock) with the same land-use history. There are few studies with this level of confidence (e.g. [8, 179]).

(ii) studies with moderately acceptable experimental designs that were carried out in stands which were growing on the same soil and bedrock with similar management and former land use. However, the stands had different ages (but were at the same stage of maturity) and were not replicated. Although we had less confidence in the design of these studies (e.g. [14, 27]), we assumed that by compiling numerous works we could detect reliable trends.

(iii) studies with weak experimental designs that were carried out in stands which were not growing on the same kind of soil. Such was the case of a study [68] which compared a spruce stand on a thick acidic soil (soil $\mathrm{pH}=$ 4.6; soil thickness $>1.5 \mathrm{~m}$; soil moisture $=87 \%$ ) with a hardwood stand on a thin neutral soil (soil $\mathrm{pH}=6.1$; soil thickness $=0.4 \mathrm{~m}$; soil moisture $=47 \%$ ). We did not use publications with weak experiment designs.

\section{NUTRIENT INPUT-OUTPUT BUDGETS}

The establishment of nutrient budgets is not required for non-intensively managed forests with high nutrient stocks. However, in the case of intensively managed forests or growing on soils poor in nutrients, the sustainability of the ecosystem may depend on nutrient budgets. As the composition of the overstory could modify the intensity of the various nutrient fluxes [70], tree species could have an impact on the input-output budget.

\subsection{Input fluxes and output fluxes}

\subsubsection{Atmospheric deposition and fixation of $\mathrm{N}_{2}$}

The capacity of trees to intercept atmospheric deposition depends on their height, leaf area index (LAI), foliage longevity, canopy structure, form or shape of leaves or needles, topographic position and the distance to the forest edge [19]. On similar soils, coniferous species usually are taller than hardwood stands of the same age [211], have a higher LAI [41], and often have persistent foliage. Thus, it is not surprising that coniferous species intercept more elements from the atmosphere, like sulphur and nitrogen, compared to hardwood species (table I). Atmospheric deposition of sulphur is 2 to 3 times higher in stands of Picea abies or Pinus sylvestris than in open areas. In stands of Fagus sylvestris or Quercus petraea the atmospheric deposition is only

Table I. Influence of tree species on atmospheric deposition.

\begin{tabular}{|c|c|c|c|c|c|c|c|c|}
\hline \multirow[t]{3}{*}{ References } & \multirow{3}{*}{$\begin{array}{l}\text { sulphur Bulk } \\
\text { Deposition } \\
\left(\mathrm{kg} \mathrm{ha}^{-1} \mathrm{yr}^{-1}\right)\end{array}$} & \multicolumn{7}{|c|}{ Tree species } \\
\hline & & $\begin{array}{c}\text { Acer } \\
\text { platanoides }\end{array}$ & $\begin{array}{c}\text { Betula } \\
\text { spp. }\end{array}$ & $\begin{array}{c}\text { Carpinus } \\
\text { betulus }\end{array}$ & $\begin{array}{c}\text { Fagus } \\
\text { sylvatica }\end{array}$ & $\begin{array}{l}\text { Picea } \\
\text { abies }\end{array}$ & $\begin{array}{l}\text { Quercus } \\
\text { spp. }\end{array}$ & $\begin{array}{c}\text { Tilia } \\
\text { cordata }\end{array}$ \\
\hline & & \multicolumn{7}{|c|}{ (deposition under canopy / bulk deposition; \%) } \\
\hline$[19]$ & 14.0 & . & . & . & +21 & +114 & . & . \\
\hline$[27]$ & 14.6 & . & +18 & . & +32 & +110 & . & . \\
\hline$[27]$ & 14.3 & . & +40 & . & +22 & +203 & . & . \\
\hline$[70]$ & 9.6 & . & . & . & +7 & +120 & . & . \\
\hline [136] & 7.9 & . & . & . & +89 & +432 & . & . \\
\hline [140] & 13.5 & . & . & +44 & +65 & . & +83 & . \\
\hline [140] & 13.9 & +107 & . & +78 & +98 & . & +163 & +76 \\
\hline [140] & 15.9 & . & . & +57 & +80 & . & +103 & . \\
\hline [167] & 10.7 & . & . & . & . & +120 & +46 & . \\
\hline [205] & 7.9 & . & . & . & +120 & +208 & . & . \\
\hline Mean & . & . & . & +60 & +59 & +187 & +99 & . \\
\hline Standard Error & . & . & . & 10 & 13 & 44 & 24 & . \\
\hline$n$ & 10 & 1 & 2 & 3 & 9 & 7 & 4 & 1 \\
\hline
\end{tabular}


twice as high, at most, than in open areas (see [179] for a detailed review of Picea abies-Fagus sylvatica comparisons).

Fixation of atmospheric nitrogen is often very low (less than $5 \mathrm{~kg} \mathrm{ha}^{-1} \mathrm{yr}^{-1}$ ) in forests where there is no symbiosis between trees and nitrogen-fixing microorganisms [193]. Some authors estimated that this flux can be more intense and may represent up to a few tens of $\mathrm{kg} \mathrm{ha}^{-1} \mathrm{yr}^{-1}$ in the presence of certain tree species (e.g. Alnus or Robinia) which have symbiotic relationships with nitrogen-fixing microorganisms (in [31]). However, $\mathrm{N}$-fixation is not a major issue in Europe where neither Alnus nor Robinia play economic roles in forestry.

\subsubsection{Nutrient input by soil mineral weathering}

Very few studies have compared the effect of overstory on mineral weathering. Indeed, the weathering flux is very difficult to estimate in situ [107]. The methods used are indirect and based on hypotheses which are difficult to verify. Although imperfect, these studies showed that some tree species, like Picea abies, promote weathering of soil minerals. The weathering rate under Picea abies was 2 to 3 times higher than under hardwood species like Fagus sylvatica, Quercus petraea or Betula spp. (table II). These results are consistent with studies carried out in the laboratory [113] and in situ [13] which showed that the mineral weathering rate was higher under Picea abies and Pinus sylvestris compared to Fagus sylvatica and Quercus petraea.

According to Drever [61] and Raulund-Rasmussen et al. [172], the major factors controlling the weathering rate of soil minerals are soil $\mathrm{pH}$ and DOC soil concentration. Some studies carried out in situ showed that soil solutions under Picea abies were more acidic and contained between 2 and 3 times more DOC or low molecular-weight complexing organic acids than soil solutions under Fagus sylvatica, Quercus petraea or Quercus

Table II. Impact of tree species on in situ weathering rates.

Table II.a - Input-output balance method.

\begin{tabular}{|c|c|c|c|c|c|c|c|c|c|c|}
\hline \multirow[t]{2}{*}{ Reference } & \multirow{2}{*}{$\begin{array}{l}\text { Depth } \\
(\mathrm{cm})\end{array}$} & \multirow[t]{2}{*}{ Localization } & \multirow[t]{2}{*}{ Bedrock } & \multirow[t]{2}{*}{ Soil } & \multirow{2}{*}{$\begin{array}{c}\text { Tree } \\
\text { species }\end{array}$} & \multirow{2}{*}{$\begin{array}{l}\text { Age } \\
\text { (yrs) }\end{array}$} & $\mathrm{K}$ & $\mathrm{Na}$ & $\mathrm{Ca}$ & $\mathrm{Mg}$ \\
\hline & & & & & & & \multicolumn{4}{|c|}{$\left(\mathrm{kg} \mathrm{ha}^{-1} \mathrm{yr}^{-1}\right)$} \\
\hline \multirow[t]{2}{*}[111]{} & watershed & Mont Lozère & granite & cambic & Picea abies & . & 6.5 & 5.1 & 11.2 & 5.5 \\
\hline & & (France) & & podzol & Fagus sylvatica & . & 3.6 & 3.8 & 2.7 & 2.4 \\
\hline \multirow[t]{3}{*}[27]{} & $(0-50)$ & Munkarp & sandy & haplic & Picea abies & 48 & 18.3 & 17.3 & 13.5 & 7.0 \\
\hline & & (Sweden) & moraine & podzol & Fagus sylvatica & 100 & 7.5 & 13.2 & 2.4 & 2.2 \\
\hline & & & & & Betula spp. & 30 & 5.1 & 3.9 & 9.9 & 2.1 \\
\hline \multirow[t]{3}{*}[27]{} & $(0-50)$ & Nythem & sandy & haplic & Picea abies & 55 & 22.9 & 64.1 & 10.6 & 9.1 \\
\hline & & (Sweden) & moraine & podzol & Fagus sylvatica & 90 & 6.6 & 15.3 & 3.9 & 1.9 \\
\hline & & & & & Betula spp. & 40 & 1.8 & 6.8 & 3.0 & 1.1 \\
\hline \multirow[t]{2}{*}[70]{} & $(0-120)$ & Vosges & granite & distric & Picea abies & 85 & 8.7 & 0.5 & 5.1 & 0.9 \\
\hline & & (France) & & cambisol & Fagus sylvatica & 140 & 3.7 & 1.4 & 1.6 & 0.4 \\
\hline
\end{tabular}

Table II.b - Isoquartz balance method.

\begin{tabular}{|c|c|c|c|c|c|c|c|c|c|c|}
\hline \multirow[t]{2}{*}{ Reference } & \multirow{2}{*}{$\begin{array}{l}\text { Depth } \\
(\mathrm{cm})\end{array}$} & \multirow[t]{2}{*}{ Localization } & \multirow[t]{2}{*}{ Bedrock } & \multirow[t]{2}{*}{ Soil } & \multirow{2}{*}{$\begin{array}{c}\text { Tree } \\
\text { species }\end{array}$} & \multirow{2}{*}{$\begin{array}{l}\text { Age } \\
\text { (yrs) }\end{array}$} & $\mathrm{K}_{2} \mathrm{O}$ & $\mathrm{Na}_{2} \mathrm{O}$ & $\mathrm{CaO}$ & $\mathrm{MgO}$ \\
\hline & & & & & & & \multicolumn{4}{|c|}{ (losses compared to bedrock; \%) } \\
\hline \multirow[t]{2}{*}{ [190] } & $(0-20)$ & Ardennes & sandstone & distric & Picea abies & 88 & -27.5 & -25.8 & +6.8 & -60.3 \\
\hline & & (Belgium) & $\&$ shales & cambisol & Fagus sylvatica & +100 & -16.4 & -5.1 & +14.6 & -35.6 \\
\hline \multirow[t]{2}{*}{ [143] } & $(0-85)$ & Ardennes & loess & distric & Picea abies & 60 & -39.0 & -9.7 & +26.3 & -31.9 \\
\hline & & (France) & & cambisol & Quercus petraea & 140 & -39.5 & -9.5 & +108.7 & -20.0 \\
\hline
\end{tabular}


robur $[14,172,197]$. As the DOC concentration in soil solutions under Pseudotsuga menziesii is intermediate compared to Picea abies and Fagus sylvatica [14], this suggests the weathering rate under Douglas-fir is also intermediate.

Tree species modify the $\mathrm{pH}$ and the composition of the complexing organic acids of soil solutions, which then influence the soil mineral weathering rate. The effect of trees on soil mineral weathering is almost exclusively located in the topsoil [13] or near the roots [55].

\subsubsection{Nutrient outputs via water seepage}

Some studies compared, in situ and over several years, the impact of different overstory species on nutrient losses via water seepage. These studies showed that Picea abies stands loose between 2 and 4 times more nutrients than Fagus sylvatica stands (table III; see [179] for a more detailed review on Picea abies-Fagus sylvatica comparisons). As for the other fluxes, the difference between these tree species varied according to the sites and the nutrients. The greater nutrient output from Picea abies stands could result from greater atmospheric deposition, particularly of mobile anions such as nitrate and sulfate. However, leaching of nutrients under Picea abies in unpolluted areas is still slightly higher than under Fagus sylvatica [179].

\subsubsection{Nutrient outputs via biomass removal}

By harvesting forest biomass, significant amounts of nutrients are exported from the ecosystem (e.g. [74, 93]). This flux is dependent on the species of trees harvested. The nutrient contents in aerial biomass are usually higher for hardwood species than for coniferous species [12, 51, $60,74,160,218]$. There are also differences within classes of tree species, for example differences exist among coniferous species [12, 66].

However, the composition of the tree layer is not the major factor influencing the nutrient loss by biomass removal. Management systems strongly influence nutrient removals through harvesting, especially: stand age at harvest is especially important: the older the stand, the lower the average nutrient content $[108,168]$. Selectivity of harvest is another factor because branches and foliage are much more concentrated in nutrients than trunks, particularly if trunks are debarked [169]. This is why wholetree harvesting causes a much higher nutrient loss (e.g. $[74,76])$ and soil acidification [147] than bole harvesting.

Ultimately, it is not possible to rank tree species in the order of their impacts on nutrient losses via biomass removal. For the same biomass, hardwood species have higher nutrient contents than coniferous species. But coniferous species produce more biomass [211] and their

Table III. Impact of tree species on deep seepage element losses.

\begin{tabular}{|c|c|c|c|c|c|c|c|c|}
\hline \multirow{2}{*}{$\begin{array}{l}\text { Reference } \\
\text { (location) }\end{array}$} & \multirow{2}{*}{$\begin{array}{c}\text { Seepage } \\
\text { depth }\end{array}$} & \multirow[t]{2}{*}{ Tree species } & K & $\mathrm{Na}$ & $\mathrm{Ca}$ & $\mathrm{Mg}$ & $\mathrm{N}$ & $\mathrm{S}$ \\
\hline & & & \multicolumn{6}{|c|}{$\left(\mathrm{kg} \mathrm{ha}^{-1} \mathrm{yr}^{-1}\right)$} \\
\hline \multirow{2}{*}{$\begin{array}{c}{[111]} \\
\text { (Lozère, France) }\end{array}$} & \multirow{2}{*}{$\begin{array}{l}\text { watershed } \\
\text { streamflow }\end{array}$} & Picea abies & 3.8 & 15.5 & 17.0 & 6.6 & 0.7 & 15.5 \\
\hline & & Fagus sylvatica & 2.7 & 13.4 & 9.3 & 3.6 & 0.2 & 10.9 \\
\hline \multirow{3}{*}{$\begin{array}{c}{[27]} \\
\text { (South Sweden) }\end{array}$} & \multirow{3}{*}{$50 \mathrm{~cm}$} & Picea abies & 5.4 & 48.4 & 11.0 & 6.6 & 12.0 & 41.1 \\
\hline & & Fagus sylvatica & 2.0 & 36.5 & 2.6 & 2.8 & 1.2 & 24.0 \\
\hline & & Betula spp. & 2.1 & 21.2 & 10.3 & 2.8 & 8.9 & 18.3 \\
\hline \multirow{3}{*}{$\begin{array}{c}{[27]} \\
\text { (South Sweden) }\end{array}$} & \multirow{3}{*}{$50 \mathrm{~cm}$} & Picea abies & 5.6 & 102.0 & 9.1 & 9.8 & 10.1 & 63.2 \\
\hline & & Fagus sylvatica & 4.4 & 33.4 & 3.7 & 3.4 & 2.7 & 19.1 \\
\hline & & Betula spp. & 2.1 & 30.6 & 5.7 & 2.9 & 3.4 & 16.7 \\
\hline \multirow{2}{*}{$\begin{array}{c}{[70]} \\
\text { (Vosges, France) }\end{array}$} & \multirow{2}{*}{$120 \mathrm{~cm}$} & Picea abies & 11.0 & 8.8 & 11.5 & 2.3 & 22.4 & 19.4 \\
\hline & & Fagus sylvatica & 3.1 & 7.1 & 2.4 & 0.8 & 2.4 & 13.5 \\
\hline \multirow{2}{*}{$\begin{array}{c}{[123]} \\
\text { (Solling, Germany) }\end{array}$} & \multirow{2}{*}{$50 \mathrm{~cm}$} & Picea abies & 3.7 & 19.5 & 14.1 & 5.8 & 15.0 & 96.6 \\
\hline & & Fagus sylvatica & 3.4 & 12.0 & 9.4 & 3.1 & 5.0 & 40.8 \\
\hline \multirow{2}{*}{$\begin{array}{c}{[144]} \\
\text { (Ardennes, France) }\end{array}$} & \multirow{2}{*}{$60 \mathrm{~cm}$} & Picea abies & 6.9 & 8.4 & 14.0 & 2.7 & 40.3 & 51.1 \\
\hline & & Quercus petraea & 3.6 & 14.3 & 11.8 & 3.6 & 13.6 & 64.0 \\
\hline
\end{tabular}


rotation lengths are lower than hardwood species. Matzner and Ulrich [122] estimated that the amount of protons released in the soil, following the uptake of cations by the trees, was higher under Picea abies (4.3 $\left.\mathrm{kg} \mathrm{ha}^{-1} \mathrm{yr}^{-1}\right)$ than under Fagus sylvatica $\left(1.3 \mathrm{~kg} \mathrm{ha}^{-1}\right.$ $\left.\mathrm{yr}^{-1}\right)$. Finally, only a study which takes into account the stand, the soil and the management can determine the effect of a biomass removal on soil fertility.

\subsubsection{Nutrient balance}

It is quite difficult to establish the input-output budget of nutrients for an ecosystem [170]. The main difficulty is in estimating precisely and independently each flux. Very few studies have compared the effect of canopy species in this scope. All the same, it seems that hardwood stands (Fagus sylvatica; Quercus petraea; Betula pendula) have a balance close to equilibrium, whereas Picea abies stands in the same location have a significantly negative balance $[27,70,144]$.

The impact of tree species on soil nutrient stock is even more difficult to demonstrate. In most studies, the effect of tree species on soil nutrient stock was either not significant or of low intensity $[35,76,218]$. The stock of exchangeable cations may increase under coniferous species, such as Picea abies or Pinus sylvestris, compared to hardwood species, such as Fagus sylvatica or Quercus petraea [36]. But the maintenance or increase of the exchangeable cation stock under some tree species, such as Picea abies, was partially due to a higher rate of mineral weathering which obscured a decrease in the total stock of nutrients in the soil [36]. However, it can not be concluded that such tree species would, over the long term, reduce the stock of nutrients to zero. An hypothesis is that some of the Picea abies stands are growing on former hardwood forest soils, and that the negative balance is the result of a change in functioning towards a new equilibrium between the soil and the overstory.
Moreover, in polluted areas, the nutrient losses of some coniferous stands are partially the result of high rates of atmospheric deposition, and would decrease as pollution is reduced in Europe.

For some nutrients, like phosphorus, it is difficult to show a constant and significant influence of overstory species on soil nutrient content because of inconsistent results $[15,171]$. The effect of tree species on total nitrogen stocks in the soil is also inconsistent. Matzner [123], Miehlich [127], Klemmedson [102] and Rothe [178] found no significant differences between broadleaves and conifers, although there were clear differences concerning the vertical distribution of nitrogen. On the other hand Kreutzer [109], Nihlgard [137] and Emberger [64] reported nitrogen stocks that were 2 to $3 \mathrm{t} \mathrm{ha}^{-1}$ higher in broadleaved stands than in Picea abies stands.

We concluded that some coniferous species, like Picea abies or Pinus sylvestris, can promote losses of nutrients, especially in regions where acidic atmospheric depositions are high. Thus, they should not be planted in the soils of these regions with low nutrients stocks. Picea abies and Pinus sylvestris growing on such soils should be managed to limit nutrient losses by wood removal (see 3.1.4.).

\subsection{Internal fluxes of the forest ecosystem}

\subsubsection{Litter and soil organic matter}

In temperate forests, the annual amount of litterfall of a mature stand is only slightly influenced by the species of the overstory because the major influences are latitude, that is climate $[177,213]$, and stand management. The average annual litterfall is between 3.5 and $4.0 \mathrm{t} \mathrm{ha}^{-1} \mathrm{yr}^{-1}$ (table IV). On the contrary, the chemical composition of foliage is dependent on tree species and site: foliage of hardwood species usually has higher concentrations of

Table IV. Mean annual litterfall under various tree species (mature stands).

\begin{tabular}{ccccccccc}
\hline Litterfall & \multicolumn{8}{c}{ Tree species } \\
\cline { 2 - 9 }$\left(\mathrm{t} \mathrm{ha}^{-1} \mathrm{yr}^{-1}\right)$ & $\begin{array}{c}\text { Betula } \\
\text { spp. }\end{array}$ & $\begin{array}{c}\text { Carpinus } \\
\text { betulus }\end{array}$ & $\begin{array}{c}\text { Fagus } \\
\text { sylvatica }\end{array}$ & $\begin{array}{c}\text { Picea } \\
\text { abies }\end{array}$ & $\begin{array}{c}\text { Pinus } \\
\text { sylvestris }\end{array}$ & $\begin{array}{c}\text { Pseudotsuga } \\
\text { menziesii }\end{array}$ & $\begin{array}{c}\text { Quercus } \\
\text { petraea }\end{array}$ & $\begin{array}{c}\text { Quercus } \\
\text { robur }\end{array}$ \\
\hline Mean & 2.2 & 2.9 & 3.5 & 3.8 & 3.9 & 3.4 & 3.7 & 3.8 \\
Std Error & 0.3 & 0.1 & 0.1 & 0.2 & 0.4 & 0.2 & 0.5 & 0.2 \\
$n$ & 3 & 11 & 43 & 44 & 20 & 23 & 6 \\
\hline
\end{tabular}

Data from: [6; 1 stand]; [16; 3 stands]; [30; 1 stand]; [31; 2 stands]; [In 47; 57 stands]; [Dambrine, com. pers.; 2 stands]; [76; 1 stand]; [In 99; 61 stands]; [121; 1 stand]; [132; 2 stands]; [138; 2 stands]; [In 139; 12 stands], [141; 9 stands]; [144; 2 stands]; [Nys, com. pers.; 1 stand]; [155; 2 stands]; [177; 6 stands]. 
$\mathrm{N}, \mathrm{K}, \mathrm{Ca}$ and $\mathrm{Mg}$ than coniferous species [28, 37, 219]. Thus, litterfall of hardwoods can be richer in nutrients than coniferous species. This effect was described by Ebermayer as early as the 19th century [63]. Nutrient input via litterfall was $12 \%$ higher for N, $200 \%$ higher for $\mathrm{Ca}$ and $400 \%$ for K in Fagus sylvatica stands compared to Pinus sylvestris stands. These findings are confirmed by more recent investigations $[44,167,178]$. Nutrient input via litterfall was 10 to $50 \%$ higher for $\mathrm{N}$ and $\mathrm{P}$ and 100 to $400 \%$ higher for $\mathrm{Ca}, \mathrm{Mg}$ and $\mathrm{K}$ in broadleaves than in conifers.

The mass of the forest floor is influenced by the overstory species. For instance, the litter weight under Picea abies could be up to twice that of hardwood species like Fagus sylvatica (table V). Indeed, the decomposition rate of litter depends on characteristics which are tree species dependent, such as hardness, morphology, lignin/ $\mathrm{N}$ ratio, foliage longevity or the content of hydrosoluble components, [1, 20, 21, 25, 76, 82, 186].

By accepting the hypothesis that the lignin/ $\mathrm{N}$ and $\mathrm{C} / \mathrm{N}$ ratios are correlated, it appeared that litters with a low decomposition rate (table $V I$ ) have a higher $\mathrm{C} / \mathrm{N}$ ratio than litters with a high rate of decomposition (table VI). So, the composition of the tree layer is a significant factor in the litter decomposition rate [133], but decomposition is strongly controlled by environmental factors [20, 21, 126].

The soil carbon content and the soil organic weight are dependent on the canopy species. Raulund-Rasmussen and Vejre [171], Belkacem et al. [22] and Gärdenäs [72] showed that Picea and Pinus stands have higher stocks of carbon than hardwoods. Abies and Pseudotsuga seemed to be intermediate.

\subsubsection{Mineralization and nitrification}

Numerous studies have provided evidence that canopy composition has an impact on nitrogen mineralization [30, 53, 54, 76, 192, 194]. Jussy [96] measured a net flux of nitrogen that was $50 \%$ greater under a Fagus sylvatica stand than under a Picea abies stand. The differences among tree species are partially because of the litter characteristics, particularly the lignin/ $\mathrm{N}$ ratio as shown by Gower and Son [76] and Scott and Binkley [186]. According to others [137, 214], there was no difference among tree species.

It should be noted that mineralization of organic matter is a source of acidity. Matzner and Ulrich [122] estimated that the acidity resulting from incomplete mineralization was $1.0 \mathrm{~kg} \mathrm{ha}^{-1} \mathrm{yr}^{-1}$ of protons under Picea abies but $0.1 \mathrm{~kg} \mathrm{ha}^{-1} \mathrm{yr}^{-1}$ under Fagus sylvatica.

Nitrification is also a flux which is influenced by tree species [53, 54, 96, 192, 194, 214]. Jussy [96] measured a net nitrification flux that was $68 \%$ greater under a Fagus sylvatica stand than under a Picea abies stand. It seems that the effect of particular tree species on nitrification is partially due to the production of components that are inhibitory to microflora. According to Howard and Howard [92] and Wedraogo et al. [215], the inhibitory capacity of litter is highest for Picea abies and lowest for hardwoods and some coniferous species like Abies alba or Pseudotsuga menziesii. However, if the overstory

Table V. Litter weight under various tree species $\left(\mathrm{t} \mathrm{ha}^{-1}\right)$.

\begin{tabular}{|c|c|c|c|c|c|c|c|c|}
\hline \multirow[t]{2}{*}{ Reference } & \multicolumn{8}{|c|}{ Tree species } \\
\hline & $\begin{array}{c}\text { Abies } \\
\text { alba }\end{array}$ & $\begin{array}{c}\text { Betula } \\
\text { spp. }\end{array}$ & $\begin{array}{c}\text { Fagus } \\
\text { sylvatica }\end{array}$ & $\begin{array}{c}\text { Picea } \\
\text { abies }\end{array}$ & $\begin{array}{c}\text { Pinus } \\
\text { sylvestris }\end{array}$ & $\begin{array}{c}\text { Pseudotsuga } \\
\text { menziesii }\end{array}$ & $\begin{array}{l}\text { Quercus } \\
\text { petraea }\end{array}$ & $\begin{array}{c}\text { Quercus } \\
\text { robur }\end{array}$ \\
\hline [8] & . & 11.0 & . & 17.0 & 19.0 & . & . & . \\
\hline$[66]$ & 44.6 & . & . & 47.2 & . & . & . & . \\
\hline [in: 31] & . & . & . & 25.7 & 45.1 & . & 36.7 & . \\
\hline [137] & . & . & 5.2 & 18.5 & . & . & . & . \\
\hline [144] & . & . & . & 37.3 & . & . & 17.3 & . \\
\hline [145] & . & . & 26.8 & 54.2 & . & 57.0 & . & 14.0 \\
\hline [149] & . & . & . & 17.4 & . & 10.9 & 6.0 & . \\
\hline [149] & . & . & 10.7 & 25.5 & 12.7 & 8.3 & 5.0 & 3.7 \\
\hline [204] & . & . & 29.7 & 49.0 & . & . & . & . \\
\hline
\end{tabular}


Table VI. C/N ratio of litter under various tree species.

\begin{tabular}{|c|c|c|c|c|c|c|c|c|}
\hline \multirow[t]{2}{*}{ Reference } & \multicolumn{8}{|c|}{ Tree species } \\
\hline & $\begin{array}{c}\text { Abies } \\
\text { alba }\end{array}$ & $\begin{array}{l}\text { Betula } \\
\text { spp. }\end{array}$ & $\begin{array}{c}\text { Fagus } \\
\text { sylvatica }\end{array}$ & $\begin{array}{r}\text { Picea } \\
\text { abies }\end{array}$ & $\begin{array}{c}\text { Pinus } \\
\text { sylvestris }\end{array}$ & $\begin{array}{c}\text { Pseudotsuga } \\
\text { menziesii }\end{array}$ & $\begin{array}{l}\text { Quercus } \\
\text { petraea }\end{array}$ & $\begin{array}{l}\text { Quercus } \\
\text { robur }\end{array}$ \\
\hline [8] & . & 31 & . & 27 & 29 & . & . & . \\
\hline [20] & 24 & . & 21 & . & . & . & . & . \\
\hline [20] & . & & 21 & & 27 & & . & . \\
\hline [20] & . & . & 18 & 21 & . & . & . & . \\
\hline [20] & . & . & . & 18 & . & . & 15 & . \\
\hline [75] & . & . & 28 & 36 & 33 & 25 & . & . \\
\hline [137] & . & . & 14 & 20 & . & . & . & . \\
\hline [144] & . & . & . & 22 & . & . & 19 & . \\
\hline [145] & . & . & 14 & 22 & . & 15 & . & 13 \\
\hline [149] & . & . & . & 46 & . & 48 & 19 & . \\
\hline [149] & . & & 22 & 41 & 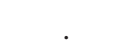 & & 22 & 19 \\
\hline [204] & . & . & 18 & 24 & . & . & . & . \\
\hline
\end{tabular}

species have an impact on the nitrification rate, the main factors influencing this rate are the climate (temperature and moisture) or the former land-use [96]. Nitrification can cause soil acidification when nitrates are leached and not taken up [175]. So, tree species which could promote nutrient losses through deep seepage, for example Picea abies, may acidify.

We conclude that some coniferous tree species have foliage which is not easily decomposed. In soils with low nutrient stocks, stands should be thinned to increase the transmittance of light, and subsequently the decomposing activity of the microflora and ultimately the turnover of nutrients.

It should be noted that all the studies mentioned deal with net mineralization (and net nitrification), in other words, fluxes calculated without taking into account the microbial immobilization of nitrogen. As the flux of microbial immobilization is quite high in forest soils, net mineralization (and nitrification) are not significantly correlated to gross mineralization [83]. This important point implies that all the hypotheses made regarding the effects of different tree species on nitrogen dynamics should be verified by taking into account the microbial immobilization of $\mathrm{NO}_{3}{ }^{-}$and $\mathrm{NH}_{4}{ }^{+}$.

\section{SOIL ACIDIFICATION}

The addition of acidic components to soils can decrease their buffering capacity (acid neutralising capacity, ANC) and/or their $\mathrm{pH}$. The effect of overstory species on soil ANC has not been widely studied, but it is established that the impact on soil $\mathrm{pH}$ is significant [148]. A canopy species can decrease soil $\mathrm{pH}$ through four basic processes [31]:

(i) species may increase the quantity of anions in soil solutions;

(ii) species may increase the quantity of acids reaching the soil. These acids originate from atmospheric deposition or biomass [122];

(iii) species may increase the degree of protonation of the stabilised soil acids. This increase could be at the origin of a lower earth-alkaline cations saturation index. For example, it has been observed that the soil saturation index under Picea abies was significantly lower than under Fagus sylvatica and Quercus petraea [15].

(iv) species may increase the strength of soil acids (lower pK; [197]). 


\subsection{Modification of soil $\mathrm{pH}$}

The effect of different tree species on soil $\mathrm{pH}$ is most significant in the first ten centimetres of the topsoil [15, $30,141]$. The $\mathrm{pH}$ difference between two tree species could be as much as $1 \mathrm{pH}$ unit in the topsoil. Nevertheless, the mean $\mathrm{pH}$ difference in soil was between 0.2 and $0.4 \mathrm{pH}$ unit (table VII). The topsoil $\mathrm{pH}$ under Picea abies and Pinus sylvestris was significantly lower than under Fagus sylvatica, Quercus petraea or Quercus robur. Abies alba and Pseudotsuga menziesii appeared to be intermediate. Norden [141] showed that Acer platanoides, Carpinus betulus and Tilia cordata had a lower acidifying impact than Fagus sylvatica or Quercus robur.

The strong acidifying impact of Picea abies probably has several origins: (i) the higher capacity of Picea abies to intercept atmospheric deposition which is potentially acidic (table I); (ii) the acidity of Picea abies and Pinus sylvestris litters [8, 21, 142, 148]; (iii) the amounts of proton which are released after the uptake of cations by trees [122]; (iv) the higher amounts of acids, and their lower pK, released under Picea abies [197]; (v) the modification of the soil microclimate (to be discussed later); and (vi) the removal of biomass (in harvested forests).
Long-term soil monitoring has shown that the species of the overstory could promote the acidification of soil by atmospheric deposition [5, 81]. Furthermore, there seem to be cyclic trends following the life cycles of stands [130]. Surface accumulation and acidity increase as stands grow. With canopy closure, microclimate becomes less favourable for organic matter decomposition.

\subsection{Modification of soil solution $\mathrm{pH}$}

The acidification of the ecosystem by some tree species could be significant with respect to the $\mathrm{pH}$ of soil solutions. Soil solution $\mathrm{pH}$ was lower under Picea abies compared to Fagus sylvatica and Quercus spp. (-0.33 pH unit; $n=10$; data from: $[14,42,58,96,105,144,197])$. This acidity may, in some cases, cause the acidification of surface waters (e.g. [7, 90]).

As modifications of the $\mathrm{pH}$ of soil and soil solutions could have an impact on the biogeochemical processes of forest ecosystems (e.g. mineral weathering of soil and faunal composition) or surface waters (discussed later), we conclude that watersheds with low acid neutralising capacity should not be planted entirely with coniferous species, like Picea abies or Pinus sylvestris, to prevent the soils and the surface waters from being acidified.

Table VII. Mean tree species inpact on topsoil $\mathrm{pH}$ (water).

\begin{tabular}{|c|c|c|c|c|}
\hline \multicolumn{3}{|c|}{ Tree species comparisons } & \multirow{2}{*}{\multicolumn{2}{|c|}{$\begin{array}{c}\text { pH Difference } \\
\text { Mean Difference }(n)\end{array}$}} \\
\hline first tree species & & second tree species & & \\
\hline Picea abies & - & Fagus sylvatica & $-0.35(n=27)$ & $* * *$ \\
\hline Picea abies & - & Quercus spp. ${ }^{\star}$ & $-0.34(n=18)$ & $* *$ \\
\hline Pinus sylvestris & - & Fagus sylvatica & $-0.27(n=5)$ & $*$ \\
\hline Pinus sylvestris & - & Quercus spp. ${ }^{\star}$ & $-0.27(n=11)$ & $* * *$ \\
\hline Abies alba & - & Fagus sylvatica & $-0.24(n=5)$ & $*$ \\
\hline Picea abies & - & Betula spp. & $-0.43(n=3)$ & n.s. $(P=0.07)$ \\
\hline Picea abies & - & Abies alba & $-0.19(n=6)$ & n.s. $(P=0.15)$ \\
\hline Pseudotsuga menziesii & - & Fagus sylvatica & $-0.22(n=8)$ & n.s. $(P=0.16)$ \\
\hline Pseudotsuga menziesii & - & Quercus spp. ${ }^{\star}$ & $-0.21(n=9)$ & n.s. $(P=0.15)$ \\
\hline Fagus sylvatica & - & Quercus spp. ${ }^{\star}$ & $-0.11(n=6)$ & n.s. $(P=0.34)$ \\
\hline Picea abies & - & Pinus sylvestris & $-0.03(n=10)$ & n.s. $(P=0.69)$ \\
\hline
\end{tabular}

$*$ significant difference $(P<0.05)$; n.s. $=$ non significant difference $(P \geq 0.05)$.

Data from: [8; 3 stands]; [15; 80 stands]; [26; 4 stands]; [27; 6 stands]; [58; 4 stands]; [86; 2 stands]; [96; 2 stands]; [105; 2 stands]; [137; 2 stands]; [148;

12 stands]; [151; 16 stands]; [166; 2 stands]; [167; 2 stands]; [171; 8 stands]; [189; 3 stands].

^ Quercus spp. refers here to Quercus petraea or Quercus robur. 


\section{WATER FLUXES AND MICROCLIMATE}

\subsection{Water fluxes}

\subsubsection{Interception of bulk precipitation}

Interception rates of different tree species have been studied intensively, however most data are applicable to Picea abies and Fagus sylvatica. (see reviews: [131, $154,158,221])$. Interception rates of conifers are usually higher than to hardwoods. The differences are most pronounced during the dormant season, when interception rates are low in hardwood stands. During the vegetative period, interception rates are also often higher in conifer stands because of higher leaf area indices [41]. Another important factor is stemflow, which is usually $<3 \%$ of throughfall precipitation for tree species with a rough bark (that is nearly all conifers, but also some hardwood species like oak), but can be 10 to $15 \%$ of throughfall precipitation for hardwood species with a smooth bark like Fagus sylvatica. Average yearly interception rates are around 25\% for hardwood species and around 35\% for coniferous species (table VIII). The differences between individual hardwood and softwood species are less pronounced and other factors may dominate the effect of the overstory species. Repeatedly it has been documented that interception rates are positively correlated with stand density $[41,131]$. Another important factor is the vertical structure of the stand. Multilayered canopies tend to intercept more water than single-layered canopies [85]. Species effects are also strongly influenced by climatic factors. In some mountain or coastal areas with a lot of mist, negative interception rates occur in conifer stands (i.e. throughfall precipitation is higher than bulk precipitation) and throughfall precipitation is higher in conifer stands than in hardwood stands [84].

\subsubsection{Transpiration}

While interception rates can be measured easily, the determination of transpiration rates on a stand level is highly complex and linked with significant uncertainties. Relatively few studies have compared the transpiration rates of different species growing next to each other (e.g. $[17,18,24,40,50,136]$. Differences among species concerning average transpiration rates tend to be small [131]. The wide range of transpiration rates for individual species (see [158]) indicates, that effects of climate and stand structure are more pronounced than effects of different tree species. The effects of conifers and hardwoods seem to be more important with respect to temporal patterns than for total water consumption. Evergreen conifer species may start transpiration as early as late winter and, depending on the climatic situation, significant transpiration rates may occur before decidious trees begin to flush [131, 178]. During the vegetation period, species effects depend on climatic and site factors. In situations with low water supply, stomatal conductance limits transpiration and the differences among species tend to be small $[119,176]$, or transpiration rates of hardwoods may be slightly lower than those of some conifer species [79]. In a situation with unlimited soil water supply and high transpirational demand of the atmosphere, maximum transpiration rates were significantly higher for Fagus sylvatica than for Picea abies [114, 178]. In this case transpiration is limited by the conductance of the roots and the matrix potential in the soil. This limitation is less severe in Fagus sylvatica stands because of higher fine root surface $[138,220]$. These patterns may explain why transpiration rates of Picea abies stands were higher [24], identical [136] or lower [178, 201] than those of Fagus sylvatica stands. The ratio between Picea abies and Fagus sylvatica may vary even within individual years $[65,178]$. In years with hot summers and

Table VIII. Bulk precipitation interception by tree species (\%).

\begin{tabular}{cccccccccc}
\hline Reference & \multicolumn{10}{c}{ Tree species } \\
\cline { 2 - 11 } & $\begin{array}{c}\text { Abies } \\
\text { alba }\end{array}$ & $\begin{array}{c}\text { Betula } \\
\text { spp. }\end{array}$ & $\begin{array}{c}\text { Carpinus } \\
\text { betulus }\end{array}$ & $\begin{array}{c}\text { Fagus } \\
\text { sylvatica }\end{array}$ & $\begin{array}{c}\text { Picea } \\
\text { abies }\end{array}$ & $\begin{array}{c}\text { Pinus } \\
\text { sylvestris }\end{array}$ & $\begin{array}{c}\text { Pseudotsuga } \\
\text { menziesii }\end{array}$ & $\begin{array}{c}\text { Quercus } \\
\text { petraea }\end{array}$ & $\begin{array}{c}\text { Quercus } \\
\text { robur }\end{array}$ \\
\hline Mean & 36 & 17 & 27 & 22 & 35 & 40 & 41 & 23 & 24 \\
Standard Error & 2 & 4 & 2 & 1 & 2 & 5 & 5 & 3 \\
$n$ & 2 & 4 & 3 & 30 & 25 & 7 & 4 & 4 & 5 \\
\hline
\end{tabular}

Data from: [3; 2 stands]; [4; 2 stands]; [17; 4 stands); [18; 2 stands]; [27; 6 stands]; [29; 6 stands]; [in: 31; 3 stands]; [Dambrine, pers. com.; 2 stands]; [71; 4 stands]; [in: 71; 2 stands]; [115; 2 stands]; [123; 2 stands]; [136; 2 stands]; [in: 139; 19 stands]; [140; 9 stands]; [178; 2 stands]; [179; 2 stands]; [188; 2 stands]; [189; 3 stands]; [206; 6 stands]; [217; 2 stands]. 
sufficient precipitation, yearly transpiration rates were higher for Fagus sylvatica than for Picea abies; in years with high temperatures in March and April and a cool summer, rates were lower for Fagus sylvatica. However, over a longer time span, transpiration rates of both species usually are of the same magnitude and differences among tree species concerning total evapotranspiration are clearly dominated by the interception of bulk precipitation.

\subsubsection{Deep-seepage water yield and soil moisture}

Deep seepage is usually higher for hardwoods (e.g. Fagus sylvatica) than for conifers because of the higher interception loss in conifer stands (e.g. Picea abies: mean, $+25 \%$; $n, 11$ pairs of stands; [179]). The proportion of bulk precipitation which leaves the rooting zone is $10 \%$ to $15 \%$ higher in Fagus sylvatica stands than in Picea abies stands. However, the quantitative effects depend strongly on climatic and site factors. In areas with low precipitation rates and less permeable soils, water yield was similar for both species [185 in: 131]. In special climatic situations, Picea abies may yield even more seepage than Fagus sylvatica [84].

Higher throughfall rates in hardwood stands influence soil moisture. Several authors reported higher topsoil moisture contents under hardwoods compared to conifers [14, 23, in: 31, 96, 137]. Similarly, Lévy [112] reported shorter periods of soil waterlogging under Picea abies and Pinus sylvestris compared to Quercus spp. and Fagus sylvatica. However, this scenario may be modified by site and climatic factors. Throughfall differences among species are most pronounced in the dormant season. In areas with sufficient precipitation, soil moisture in conifer stands is high (above field capacity) during winter time, and additional input of rain effects seepage rates rather than soil moisture. In such a situation, soil moisture during winter time is similar in conifer and hardwood stands [178, 185]. Soil moisture is generally lower in conifer stands in early spring, since transpiration in conifers starts before the leaves of deciduous trees flush. During summertime, soil moisture may be even lower in hardwood stands because of higher transpiration rates during periods with high transpirational demands $[114,131]$. Another important consideration is the morphology of the fine root system. The deeper rooted species Fagus sylvatica takes up more water from the subsoil, leading to a lower soil moisture compared to the shallow rooted species Picea abies.

\subsection{Microclimate}

\subsubsection{Light transmittance}

The influence of different tree species on light transmittance has been widely observed (e.g. [56, 162]) or measured [46]. Indeed, light transmittance is negatively correlated with canopy cover and to LAI $[34,46]$ which are also tree species dependent [34, 41, 46, 103]. Considering North American tree species, light transmittance is lower under coniferous species than under hardwood species [34, 46]. Among European tree species, Abies alba, Picea abies, and sometimes Fagus sylvatica, transmit low levels of light [94, 100, 137]. However, silvicultural management, particularly the initial stand density and the thinning intensity, can greatly modify light transmittance [57].

\subsubsection{Air temperature and moisture}

Lower light transmittance appears to lower temperature slightly under Picea abies compared to other tree species such as Fagus sylvatica [135] and Pinus sylvestris [17]. Pasak [157] reported a decrease in the thermic amplitude under Picea abies compared to a mixed stand of Quercus spp. and Pinus sylvestris. On the contrary, Vanseren [212] did not observe any temperature difference between Picea abies and Fagus sylvatica.

Nihlgard [135] measured air moisture in a Picea abies stand and a Fagus sylvatica stand, and found more humidity in the Picea abies stand.

We conclude that species of the trees in the overstory has significant effects on water fluxes and microclimate. However, these effects are highly dependant on other factors, like forest management, climate and soil characteristics.

\section{FOREST COMMUNITIES AND PHYSICAL FEATURES OF SOIL}

\subsection{Modification of forest communities}

\subsubsection{Understory}

According to several studies [62, 101, 103, 104, 150], the composition and the amount of cover in the understory are dependent on the species of trees present in the overstory. The different tree species may influence the understory differently by modifying the transmittance 
of the light [150], the microclimate, the characteristics of the forest floor $[162,198,199]$ and the soil, or by releasing toxic compounds [159]. However, there is no consensus about the effects of different tree species on understory species richness and floral diversity $[9,15$, $45,67,89,101,116,161]$. Even so, it seems that some coniferous species with dense canopies (e.g. Picea abies, Abies alba or Pseudotsuga menziesii) probably reduce the cover of ground vegetation, especially for spring flora [150, 162]. Moreover, moss cover is higher and herb cover is lower under Picea abies compared to hardwood species [15, 87, 129, 182, 187].

Factors such as silvicultural management [43], human and former land-use [106, 161], and atmospheric deposition [69] could impact the understory which more seriously than the overstory species. According to Hill [88], the ground vegetation under coniferous species such as Picea abies is not significantly different from that of the understory of a hardwood stand if the coniferous stand has been heavily thinned.

\subsubsection{Soil microflora}

Soil bacteria play an important role in soil processes. For instance, bacteria can decrease mineral alteration by decomposing weathering organic components [117], or they can increase it by producing organic acids $[38,113]$.

Soil microflora seems to be strongly influenced by the species of the overstory [20]. Mardulyn et al. [120] observed that the biomass and the activity of the soil microflora under Fagus sylvatica were higher than under Picea abies. However, the complexity of the interaction between different tree species and microflora sensus lato is too high for generalisations [159]. Even if most tree species produce compounds inhibitory to the soil bacteria $[20,139]$, there is no strong evidence that this process is the only one involved in the relationship between tree species and soil microflora.

Mycorrhizes also play an important role in soil processes, like mineral weathering by producing complexing organic acids [113, 153, 208]. Tyler [202] showed that numerous fungi which are symbiotic with trees are present only in soils under particular tree species.

\subsubsection{Soil fauna}

Different tree species influence the composition and the abundance of soil fauna differently, particularly the litter fauna [59, 139, 163]. Under Pinus sylvestris, Pseudotsuga menziesii or Picea abies, earthworm density is lower than under hardwood species or Abies alba [31, 139]. Saetre [183] also observed this same effect in a comparison of Picea abies and Betula pendula.

When litter from one tree species is placed under a stand composed of another species but growing on the same soil, the litter may decompose more slowly [125]. This observation suggests that the decomposition rate of litter from a particular tree species depends on the presence of particular soil fauna and microflora.

\subsection{Modification of physical features}

The composition of the overstory has an impact on soil structure [173]. In an artificial soil, Graham et al. $[77,78]$ have shown that the soil structure and its stability were tree species dependent, probably because of differential effects on worm activity.

In Europe, Grieve [80] and Nys et al. [145] estimated that the structural stability of soil was lower under Picea abies compared to Quercus spp. and Fagus sylvatica. Challinor [48] and Nihlgard [137] have measured lower water infiltration rates in soils under Picea abies compared to other tree species. This finding could be linked to the lower porosity under Picea abies observed by Nys et al. [145]. However, the long term effects of Picea abies on soil structure and porosity are still unclear and site factors seem to play an important role. Much work on this topic has been done in Germany because of concerns that long-term cultivation of Picea abies may have negative impacts on the physical properties of soil (see overview [174]). On loamy glacial soils there was no evidence that long-term mono-cultivation of Picea abies decreased the porosity of the soil. In some cases, pore volume in the uppermost mineral soil was actually higher in Picea abies stands than in broadleaf stands (this was attributed to root movement of shallow-rooting Picea abies during windy periods).

We conclude that the effect on forest communities having different tree species in the canopy is significant. Although there is no strong evidence of a decrease in floral diversity under coniferous species, it appears that other communities like soil microflora or microfauna changed under some coniferous species such as Picea abies. However, no clear effect of this tree species via effects on worm activity has been demonstrated. 


\section{CONSEQUENCES ON SOIL FERTILITY}

\subsection{Localisation and intensity of soil modifications}

On the time scale of a few decades, the impact of the species of the overstory on soil characteristics is often significant only in the forest floor and the ten first centimetres of topsoil $[15,30,49]$, or near the roots $[10,113$, 191]. The intensity of this impact is positively correlated with the stand density [180].

The effect of the overstory species could also extend to ecosystems larger than the forest stand, notably in surface waters. It has been established that the cultivation of some coniferous tree species on soils with low ANC could acidify and increase the toxic $\mathrm{Al}^{3+}$ content of surface waters $[7,91,156]$. This phenomenon could extirpate trout populations [164].

\subsection{Groups of tree species according to their impact}

Our understanding of the effects of tree species on soils remains very incomplete, but the available information allows us to suggest some rankings of species with respect to their potential effects on soil fertility. Foresters and scientists may not uniformly agree these rankings, but we hope that in coming decades, the ranks can be tested more thoroughly and revised as necessary.

\subsubsection{Acidity}

Based on current knowledge, we would rank these tree species in the order of decreasing acidifying ability, as follows: (Picea abies; Picea sitchensis; Pinus sylvestris $) \geq($ Abies alba; Pseudotsuga menziesii) $\geq$ (Betula pendula; Fagus sylvatica; Quercus petraea; Quercus robur $) \geq$ (Acer platanoides; Carpinus betulus; Fraxinus excelsior; Tilia cordata).

According to Vanmechelen et al. [210], 65\% of European forest topsoils are acidic $\left(\mathrm{pH}_{\mathrm{CaCl} 2} \leq 4.5\right)$ and more than $30 \%$ of soils are desaturated (BS $\leq 15 \%$ ). As highly acidic conditions could be an important problem for forest growth, we recommand that tree species with high acidifying impact, like Picea abies, not be planted on soils with a very low buffering capacity, especially if the area receives a high amount of acidic atmospheric deposition. We would also discourage the planting of acidifying species on the entire surface area of watersheds with low buffering capacity. The acidifying impact of a tree species can be reduced by managing it in mixed stands at low densities and by exporting low amounts of nutrients during wood harvests.

Alternatively, the ability of some coniferous species to acidify and weather soil minerals could be useful, for instance in thin calcerous soils, for increasing the stock of exchangeable cations.

\subsubsection{Tree nutrition}

The limitation of tree growth by lack of nutrients is usually the result of $\mathrm{N}, \mathrm{Ca}, \mathrm{Mg}$ or K deficiencies [110]. In central Europe, $\mathrm{N}$ nutrition is naturally deficient but it seems to be compensated for by atmospheric deposition; this is not the case in the rest of Europe [110]. Potassium deficiencies often occur in dense stands on calcarous soils associated with droughts [110]. Thus, the K deficiency on calcarous soils seems to be the consequence of climate and silviculture more than overstory species. Calcium and magnesium deficiencies are also associated with droughts and dense stands but they are encountered in acidic soils developed on bedrocks very poor in these elements [110]. As $\mathrm{Ca}$ and $\mathrm{Mg}$ deficiencies can be promoted strongly by soil acidification and nutrient turnover, some coniferous species have the capacity to reduce the nutrient turnover at a site because of the quality of their litterfall and dead roots (e.g. lignin/ $\mathrm{N}$ ratio, hardness, etc.), and because of their capacity to produce particular organic components (e.g. complexing acids, toxic inhibitory components, etc.), we would discourage cultivation of acidifying tree species or tree species which limit the nutrient turnover in very poor soils. However, the effect of overstory species is strongly influenced by forest management (e.g. low density stands or mixed stands can promote litter decomposition).

\subsubsection{Water fluxes}

It is quite clear that overstory species modify water fluxes: some coniferous species have higher interception and lower deep seepage fluxes compared to hardwoods. This characteristic, and the characteristics of the area, should be taken into account by the forest manager in selecting tree species for planting. 


\subsubsection{Forest communities and physical features of soil}

Even if the effect of overstory species was significant on the composition of many communities and on some physical features of soil, it was not possible to establish a general rule. Indeed, as previously said, the effect of tree species is closely linked to forest management.

\subsection{Mixed stands}

Mixed stands are often, but not always, intermediate compared to monospecific stands in terms of several processes. These processes are acidification [36], atmospheric deposition [180], soil fauna and microflora composition [97, 128, 163, 184], and species composition of communities in general [48, 73]. Moreover, mixed stands have better nitrogen and phosphorus nutrition [180]. However, it seems that there are no general rules about the effects of mixed stands on litter decomposition, nitrification, mineralization, soil nutrient availability or biomass increment [180]. For these variables, the effect of the species mix depends on its composition and also strongly on the site characteristics.

\subsection{Interactions between natural and human factors}

The impact of an overstory species on soil varies significantly with factors like climate, geology and silvicultural management. Thus, the soil carbon stock, the $\mathrm{C} / \mathrm{N}$ ratio and degradability of litter, mineral weathering and microflora composition depend on the species of the overstory (see previous discussion) but they also depend strongly on soil type and climate [20, 22, 36, 126]. For instance, if some tree species such as Picea abies, Picea sitchensis or Pinus sylvestris can promote soil podzolisation [86, 130, 134, 190], then this soil process does not occur if climate and geology are not predisposed to it [118]. In the same way, the so-called "improving" tree species can not prevent a soil from being podzolized if the environmental factors are very predisposed to it.

The form of silvicultural management is also a very important factor. Indeed, the effects of different overstory species on nutrient losses by biomass removal, or understory composition, depend strongly on the silvicultural management [88, 43, 168]. Moreover, the influence of the tree species on the ecosystem varies during the rotation of the stand $[152,195]$.

\subsection{Biological value of a site, the resiliency of the soil and the choice of tree species}

Before considering the choice of a tree species for a plantation, the manager should take into account the ecological and landscape values of the site. Based on these values, it may be better to not modify an ecosystem, or group of ecosystems, which has a high biological value (e.g. rare species) or an important landscape function (e.g. protection from soil erosion). When the site does not have a high ecological or landscape value, it is important to estimate the amount of wood production that is sustainable by the ecosystem without jeopardizing its numerous other functions [98]. It is possible to broadly quantify the soil resiliency to acidification by estimating its buffering capacity [207], its total reserve of basic cations [39], or by taking into account the general characteristics of the site [11]. On sites where the soil resiliency is low and where there is no restitution of fertility (e.g. liming), tree species with a high impact on soil should not be planted in dense stands and over large areas. In soil with a high resiliency all kinds of tree species can be planted.

\section{CONCLUSION}

Overstory composition significantly influences the physical, chemical and biological characteristics of topsoil. By modifying the fluxes of matter or energy, the trees have the potential to impact the current soil fertility. To ensure the sustainable management of forests, the resiliency of the ecosystems should be estimated to determinate the most appropriate tree species and silvicultural management. However, the tree species factor is strongly influenced by other factors like climate, pollution or geology. Therefore, the tree species should not be the only consideration during the planning of the forest management.

Many complementary studies are needed to better understand the effect of tree species selection on long-term fertility. One of the soil parameters which may be very interesting to investigate is the $\mathrm{N}$ dynamic because it is not clearly understood. These studies might be designed to limit possible biases by considering replicate stands under the same conditions and by using careful quality assurance procedures.

Acknowledgements: We are very thankful to Drs. Dijkstra, Jandl and Templer for their very relevant comments and criticisms. We also thank Ms. Gerson for revising the English of all this work. 


\section{REFERENCES}

[1] Aber J.D., Melillo J.M., Litter decomposition: measuring relative contributions of organic matter and nitrogen to forest soils, Can. J. Bot. 58 (1982) 416-421.

[2] Adamson J.K., Hornung M., Kennedy V.H., Norris D.A., Paterson I.S., Stevens P.A., Soil solution chemistry and throughfall under adjacent stands of Japanase Larch and Sitka Spruce at three contrasting locations in Britain, Forestry 66 (1993) 51-68.

[3] Agster G., Ein- und Austrag sowie Umsatz gelöster Stoffe in den Einzugsgebieten des Schönbuchs, in: Einsele G. (Ed.), Das landschaftsökologische Projekt Schönbuch, Verlag VCH, Weinheim, 1986, 343-356.

[4] Ahmad-Shah A., Rieley J.O., Influence of tree canopies on the quantity of water and amount of chemical elements reaching the peat surface of a basin mire in the Midlands of England, J. Ecol. 77 (1989) 357-370.

[5] Ahokas H., Acidification of forest top soils in 60 years to the southwest of Helsinki, For. Ecol. Manage. 94 (1997) 187-193.

[6] Alexander C.E., Cresser M.S., An assessment of the possible impact of expansion of native woodland cover on the chemistry of Scottish freshwaters, For. Ecol. Manage. 73 (1995) 1-27.

[7] Allott N., Brennan M., Mills P., Eacrett A., Stream chemistry and forest cover in ten small western Irish catchments, in: Watkins C. (Ed.), Ecological effects of forestation, Redwood Press, Melksham, UK, 1993, pp. 165-177.

[8] Alriksson A., Eriksson H.M., Variations in mineral nutrient and $\mathrm{C}$ distribution in the soil and vegetation compartments of five temperate tree species in NE Sweden, For. Ecol. Manage. 108 (1998) 261-273.

[9] Amezaga I., Onaindia M., The effect of evergreen and deciduous coniferous plantations on the field layer and seed bank of native woodlands, Ecography 20 (1997) 308-318.

[10] April R., Keller D., Mineralogy of the rhizosphere in forest soils of the eastern United States. Mineralogic studies of the rhizosphere, Biogeochemistry 9 (1990) 1-18.

[11] Augusto L., Ranger J., Bonneau M., Choix des essences forestières lors des opérations de plantation. Conséquences sur la fertilité des sols, Rev. For. Fr. 52 (2000) 507-518.

[12] Augusto L., Ranger J., Ponette Q., Rapp M., Relationships between forest tree species, stand production and stand nutrient amount, Ann. For. Sci. 57 (2000) 313-324.

[13] Augusto L., Turpault M.P., Ranger J., Impact of tree species on feldspar weathering rates, Geoderma 96 (2000) 215-237.

[14] Augusto L., Ranger J., Impact of tree species on soil solutions in acidic conditions, Ann. For. Sci. 58 (2001) 47-58.

[15] Augusto L., Dupouey J.L., Ranger J., Effects of tree species on understory vegetation and environmental conditions in temperate forests, Ann. For. Sci., to be published.

[16] Aussenac G., Bonneau M., Le Tacon F., Restitution des éléments minéraux au sol par l'intermédiaire de la litière et des précipitations dans quatre peuplements forestiers de l'est de la France, Oecol. Plant. 7 (1972) 1-21.
[17] Aussenac G., Couverts forestiers et facteurs du climat: Leurs interactions, conséquences écophysiologiques chez quelques résineux, Thèse de Doctorat, Université de Nancy I, 1975, $234 \mathrm{p}$.

[18] Aussenac G., Boulangeat C., Interception des précipitations et évaporation réelle dans des peuplements de feuillus ( $\mathrm{Fa}$ gus sylvatica L.) et de résineux (Pseudotsuga menziesii (Mirb) Franco), Ann. Sci. For. 37 (1980) 91-107.

[19] Balsberg-Pahlsson A.M., Bergkvist B., Acid deposition and soil acidification at a southwest facing edge of Norway spruce and European beech in south Sweden, Ecol. Bull. 44 (1995) $43-53$.

[20] Bauzon D., van der Driessche R., Dommergues Y., L'effet litière. I - Influence in situ des litières forestières sur quelques caractéristiques biologiques des sols, Oecol. Plant. 4 (1969) 99-122.

[21] Beck G., Dommergues Y., van der Driessche R., L'effet litière. II - Étude experimentale du pouvoir inhibiteur des composés hydrosolubles des feuilles et des litières forestières vis-à-vis de la microflore tellurique, Oecol. Plant. 4 (1969) 237-266.

[22] Belkacem D., Nys C., Dupouey J.L., Évaluation des stocks de carbone dans les sols forestiers. Importance de la sylviculture et du milieu sur la variabilité, Rapport AIP AGRIGES, Ministère de l'environnement, n⿳6 - 95/329/P00006, 1998, 68 p.

[23] Benecke P., Mayer R., Aspects of soil water behavior as related to beech and spruce stands. Some results of the water balance investigations, in: Ellenberg H. (Ed.), Integrated experimental ecology - Methods and results of ecosystem research in the german Solling project, Ecological Vol. 2., Springer-Verlag, Berlin Heidelberg, New York, 1971, pp. 153-163.

[24] Benecke W., Ellenberg H., Umsatz und Verfügbarkeit des Wassers im Buchen- und Fichtenbestand, in: Ellenberg H., Mayer R., Schauermann J., (Hrsg.), Ökosystemforschung Ergebnisse des Sollingprojektes 1966-1986, Ulmer Verlag, Stuttgart, 1986, 356-374.

[25] Berg B., Nutrient release from litter and humus in coniferous forest soils - a mini review, Scand. J. For. Res. 1 (1986) 359-369.

[26] Bergkvist B., Leaching of metals from forest soils as influenced by tree species and management, For. Ecol. Manage. 22 (1987) 29-56.

[27] Bergkvist B., Folkeson L., The influence of tree species on acid deposition, proton budgets and element fluxes in south Swedish forest ecosystems, Ecol. Bull. 44 (1995) 90-99.

[28] Bergmann W., Ernährungsstörungen bei Kulturpflanzen. Entstehung, visuelle und analytishe diagnose, Bergmann W. (Ed.), $2^{\mathrm{e}}$ édition, Gustav Fisher Verlag, Stuttgart, 1988, 762 p.

[29] Bille-Hansen J., Hansen K., The Element Cycling Project, 1985-1996. Studies of nutrient cycling in 3 conifer species and two deciduous on 3 forest districts: Ulborg, Lindet and Frederiksborg., The Research Series, 1999. [in Danish with English abstract].

[30] Binkley D., Valentine D., Fifty-year biogeochemical effects of green ash, white pine and Norway spruce in a replicated experiment, For. Ecol. Manage. 40 (1991) 13-25. 
[31] Binkley D., The influence of tree species on forest soils: Processes and Patterns, in: Mead D.J., Cornforth I.S. (Eds.), Proceedings of the trees and soil workshop. 1994. Agronomy Society of New Zealand Special Publication \#10, Lincoln Univ. Press, Canterbury, NZ, 1996, pp. 1-33.

[32] Binkley D., Giardina C., Why do tree species affect soils? The warp and woof of tree-soil interactions, Biogeochemistry 42 (1998) 89-106.

[33] Boettcher S.E., Single-tree influence on soil properties in the mountains of eastern Kentucky, Ecology 71 (1990) $1365-1372$

[34] Bolstad P.V., Gower S.T., Estimation of leaf area index in fourteen southern Wisconsin forest stands using a portable radiometer, Tree Physiol. 7 (1990) 115-124.

[35] Bonneau M., Brethes A., Nys C., Souchier B., Influence d'une plantation d'épicéas sur un sol du Massif Central, Lejeunia, nouvelle série 82 (1976) 165-177.

[36] Bonneau M., Brethes A., Lelong F., Lévy G., Nys C., Souchier B., Effets de boisements résineux purs sur l'évolution de la fertilité du sol, Rev. For. Fr. 31 (1979) 198-207.

[37] Bonneau M., Le diagnostic foliaire, Rev. For. Fr. 40 (1988) 19-26.

[38] Boyle J.R., Voigt G.K., Biological weathering of silicate minerals. Implications for tree nutrition and soil genesis, Plant Soil 38 (1973) 191-201.

[39] Brahy V., Deckers J., Delvaux B., Estimation of soil weathering stage and acid neutralizing capacity in a toposequence Luvisol-Cambisol on loess under deciduous forest in Belgium, Eur. J. Soil Sci. 51 (2000) 1-13.

[40] Bréda N., Cochard H., Dreyer E., Granier A., Field comparison of transpiration, stomacal conductance and vulnerability to cavitation of Quercus petraea and Quercus robur under water stress, Ann. Sci. For. 50 (1993) 571-582.

[41] Bréda N., L'indice foliaire des couverts forestiers: mesure, variabilité et rôle fonctionnel, Rev. For. Fr. 56 (1999) 135-150.

[42] Brown A.H.F., Iles M.A., Water chemistry profiles under four tree species at Gisburn, NW England, Forestry 64 (1991) 169-187.

[43] Brunet J., Falkengren-Grerup U., Tyler G., Herb layer of south swedish beech and oak forests-effects of management and soil acidity during one decade, For. Ecol. Manage. 88 (1996) 259-272.

[44] Bücking W., Evers F.H., Krebs A., Stoffdeposition in Fichten- und Buchenbeständen des Schönbuchs und ihre Auswirkungen auf Boden und Sickerwasser verschiedener Standorte, in: Einsele G. (Ed.), Das landschaftökologische Projekt Schönbuch. Verlag VCH, Weinheim, 1986, pp. 271-324.

[45] Bürger R., Immissionen und Kronenverlichtungen als Ursachen für Veränderungen der Waldbodenvegetation im Schwarzwald, Tuexenia 11 (1991) 407-424

[46] Canham C.D., Finzi A.C., Pacala S.W., Burbank D.H., Causes and consequences of resource heterogeneity in forests: interspecific variation in light transmission by canopy trees, Can. J. For. Res. 24 (1994) 337-349.
[47] Cannell M.G.R., World forest biomass and primary production data, Academic press, London, 1982, 382 p.

[48] Cannell M.G.R., Environmental impacts of forest monocultures: water use, acidification, wildlife conservation, and carbon storage, New Forests 17 (1999) 239-262.

[49] Challinor D., Alteration of surface soil characteristics by four tree species, Ecology 49 (1968) 286-290.

[50] Cienciala E., Kucera J., Lindroth A., Cermak J., Grelle A., Halldin S., Canopy transpiration from a boreal forest in Sweden during a dry year, Agri. For. Meteo. 86 (1997) 157-167.

[51] Cole D.W., Rapp M., Elemental cycling in forest ecosystems, in: Reichle D.E. (Ed.), Dynamic properties of forest ecosystems, Cambridge Univ. Press, 1980, pp. 341-409.

[52] Communautés européennes - Parlement européen, L'Europe et la forêt, Office des publications officielles des communautés européennes, Luxembourg, 1994, 1528 p.

[53] Compton J.E., Boone R.D., Motzkin G., Foster D.R., Soil carbon and nitrogen in a pine-oak sand plain in central Massachussets: Role of vegetation and land-use history, Oecologia 116 (1998) 536-542.

[54] Côté L., Brown S., Paré D., Fyles J., Bauhus J., Dynamics and nitrogen mineralization in relation to stand type, stand age and soil texture in the boreal mixedwood, Soil Biol. Biochem. 32 (2000) 1079-1090.

[55] Courchesne F., Gobran G.R., Mineralogical variations of bulk and rhizosphere soils from a Norway spruce stand, Soil Sci. Soc. Am. J. 61 (1997) 1245-1249.

[56] Crozier C.R., Boerner R.E.J., Correlations of understory herb distribution patterns with microhabitats under different tree species in a mixed mesophytic forest, Oecologia 62 (1984) 337-343.

[57] Cutini A., The influence of drought and thinning on leaf area index estimated from canopy transmittance method, Ann. Sci. For. 53 (1996) 595-603.

[58] Davis M.R., Chemical composition of soil solutions extracted from New Zealand beech forests and West German beech and spruce forests, Plant Soil 126 (1990) 237-246.

[59] Deharveng L., Soil Collembola diversity, Endemism, and reforestation: A case study in the Pyrenées (France), Conserv. Biol. 10 (1996) 74-84.

[60] Denayer-de Smet S., Duvigneaud P., Comparaison du cycle des polyéléments biogèens dans une hêtraie et une pessière établies sur même roche-mère, à Mirwart, Bull. Soc. Roy. Bot. Belg. 105 (1972) 197-205.

[61] Drever J.I., The effect of land plants on weathering rates of silicate minerals, Geochim. Cosmochim. Acta 58 (1994) $2325-2332$.

[62] Dzwonko Z., Loster S., Effect of dominant trees and anthropogenic disturbances on species richness and floristic composition on secondary communities in Southern Poland, J. Appl. Ecol. 34 (1997) 861-870.

[63] Ebermayer E., Die gesamte Lehre der Waldstreu mit Rücksicht auf die chemische Statik des Waldbaues, Berlin, 1876. 
[64] Emberger S., Die Stickstoffvorräte bayrischer Waldböden, Forstwiss. Centralbl. 84 (1965) 156-193.

[65] Ernstberger H., Einfluß der Landnutzung auf Verdunstung und Wasserbilanz: Bestimmung der aktuellen Evapotranspirstion von unterschiedlich genutzten Standorten zur Ermittlung der Wasserbilanz von Einzugsgebieten in unteren Mittelgebirgslagen Hessens. Beiträge zur Hydrologie, Kirchzarten, 1987.

[66] Eriksson H.M., Rosén K., Nutrient distribution in a swedish tree species experiment, Plant Soil 164 (1994) 51-59.

[67] Ewald J., The influence of coniferous canopies on understory vegetation and soils in mountain forests of the northern Cacereous Alps, Appl.Veg Sci. 3 (2000) 123-134

[68] Fahy O., Gormally M., A comparison of plant and carabid beetle communities in an irish oak woodland with a nearby conifer plantation and clearfelled site, For. Ecol. Manage. 110 (1998) 263-273.

[69] Falkengren-Grerup U., Long-term changes in flora and vegetation in deciduous forests of southern Sweden, Ecol. Bull. 44 (1995) 215-226.

[70] Fichter J., Dambrine E., Turpault M.P., Ranger J., Base cation supply in spruce and beech ecosystems of the Strengbach catchment (Vosges mountains, N-E France), Water Air Soil Pollut. 105 (1998) 125-148.

[71] Forgeard F., Gloaguen J.C., Touffet J., Interception des précipitations et apports au sol d'éléments minéraux par les eaux de pluie et les pluviolessivats dans une hêtraie atlantique et dans quelques peuplements résineux de Bretagne, Ann. Sci. For. 37 (1980) 53-71.

[72] Gärdenäs A.I., Soil organic matter in european forest floors in relation to stand characteristics and environmental factors, Scand. J. For. Res. 13 (1998) 274-283.

[73] Gjerde I., Saetersdal M., Effects on avian diversity of introducing spruce Picea spp. plantations in the native pine Pinus sylvestris forests of western Norway, Biol. Conserv. 79 (1997) 241-250.

[74] Glatzel G., The nitrogen status of Austrian forest ecosystems as influenced by atmospheric deposition, biomass harvesting and lateral organomass exchange, Plant Soil 128 (1990) 67-74.

[75] Gloaguen J.C., Touffet J., Évolution du rapport C/N dans les feuilles et au cours de la décomposition des litières sous climat atlantique. Le hêtre et quelques conifères, Ann. Sci. For. 39 (1982) 219-230.

[76] Gower S.T., Son Y., Differences in soil and leaf litterfall nitrogen dynamics for five forest plantations, Soil Sci. Soc. Am. J. 56 (1992) 1959-1966.

[77] Graham R.C., Wood H.B., Morphologic development and clay redistribution in lysimeter soils under Chaparral and Pine, Soil Sci. Soc. Am. J. 55 (1991) 1638-1646.

[78] Graham R.C., Ervin J.O., Wood H.B., Agregate stability under oak and pine after four decades of soil development, Soil Sci. Soc. Am. J. 59 (1995) 1740-1744.

[79] Granier A., Bréda N., Biron P., Villette S., A lumped water balance model to evaluate duration and intensity of drought constraints in forest stands, Ecol. Modelling 116 (1999) 269-283.
[80] Grieve I.C., Some effects of the plantation of conifers on a freely drained lowland soil, Forest of Dean, UK, Forestry 51 (1978) 21-28.

[81] Hallbäcken L., Tamm C.O., Changes in soil acidity from 1927 to 1982-1984 in a forest area of south-west sweden, Scand. J. For. Res. 1 (1986) 219-232.

[82] Harmon M.E., Baker G.A., Spycher G., Greene S.E., Leaf-litter decomposition in the Picea/Tsuga forests of Olympic National Park, Washington, USA, For. Ecol. Manage. 31 (1990) 55-66.

[83] Hart S.C., Nason G.E., Myrold D.D., Perry D.A., Dynamics of gross nitrogen transformations in an old-growth forest: the carbon connection, Ecology 75 (1994) 880-891.

[84] Heil K., Wasserhaushalt und Stoffumsatz in Fichten- (Picea abies (L) Karst.) und Buchenökosystemen (Fagus sylvatica L.) der höheren Lagen des Bayer. Waldes, Ph.D. thesis, Univ. München, 1996.

[85] Heitz R., Rehfuess K.E., Reconversion of Norway spruce (Picea abies L.) stands into mixed forests: effects on soil properties and nutrient fluxes, in: Mangement of mixed-species forest: silviculture and economics, Olsthoorn A.F.M. (Ed.) IBN Scientific contributions 15, Institute for Forestry and Nature Research, Wageningen NL, 1999, pp. 37-45.

[86] Herbauts J., de Buyl E., The relation between spruce monoculture and incipient podzolisation in ochreous brown earths of the belgian Ardennes, Plant Soil 60 (1981) 33-49.

[87] Hill M.O., Jones E.W., Vegetation changes resulting from afforestation of rough grazings in Caeo forest, south Wales, J. Ecol. 66 (1978) 433-456.

[88] Hill M.O., 1987. Opportunities for vegetation management in plantation forest, in: Good, J.E.G. (Ed.), Environmental aspects of plantation forestry in Wales, Institute of Terrestrial Ecology, UK, pp. 64-69.

[89] Hong Q., Klinka K., Sivak B., Diversity of the understory vascular vegetation in 40 year-old and old-growth forest stands on Vancouver island, British Columbia, J. Veg. Sci. 8 (1997) 778-780.

[90] Hornung M., Reynolds B., Stevens P.A., Hugues S., Water quality changes from input to stream, in: Edwards R.W. (Ed.), Acid waters in Wales, Kluwer Academic Publishers, Dordrecht, NL, 1990, pp. 223-240.

[91] Hornung M., Reynolds B., The effects of natural and anthropogenic environmental changes on ecosystem processes at the catchment scale, Trends Ecol. Evol. 10 (1995) 443-449.

[92] Howard P.J.A., Howard D.M., Inhibition of nitrification by aqueous extracts of tree leaf litters, Rev. Ecol. Biol. Sol 28 (1991) 255-264.

[93] Huntington T.G., Hooper R.P., Johnson C.E., Aulenbac B.T., Cappellato R., Blum A.E., Calcium depletion in a Southeastern United States forest ecosystem, Soil Sci. Soc. Am. J. 64 (2000) 1845-1858.

[94] Jacquiot C., La forêt, Masson (Ed.), Paris, 1970, 160 p.

[95] Joffe J.S., Pedology, Pedology Publications, 2nd Edition, News Brunswick, 1949, 662 p. 
[96] Jussy J.H., Minéralisation de l'azote, nitrification et prélèvement radiculaire dans différents écosystèmes forestiers sur sol acide. Effets de l'essence, du stade de développement du peuplement et de l'usage ancien des sols, Thèse de Doctorat, Université de Nancy I, 1998, 161 p.

[97] Kaneko N., Salamanca E.F., Mixed leaf litter effects on decomposition rates and soil microarthropod communities in an oak-pine stand in Japan, Ecol. Res. 14 (1999) 131-138.

[98] Kimmins J.P., Sustained yield, timber mining, and the concept of ecological rotation; a British Columbian view, For. Chron. Feb (1974) 27-31.

[99] Kimmins J.P., Binkley D., Chatarpaul L., Catanzaro de J., Biochemistry of temperate forest ecosystems: Litterature on inventories and dynamics of biomass and nutrients, Information Report PI-X-47 E/F, Government of Canada, Canadian Forestry Service, 1985, $227 \mathrm{p}$.

[100] Kimmins J.P., Forest Ecology, Mc Millan Publ. Comp. New York, Collier Mac Millan Publ., London, 1987.

[101] Kirby K.J., Changes in the ground flora under plantations on ancient woodland sites, Forestry 61 (1988) 317-338.

[102] Klemmedson J.O., Influence of oak in pine forests of Central Arizona on selected nutrients of forest floor and soil, Soil Sci. Soc. Am. J. 51 (1987) 1623-1628.

[103] Klinka K., Chen H.Y.H., Wang Q., de Montigny L., Forest canopies and their influence on understory vegetation in early-seral stands on West Vancouver island, Northwest Sci. 70 (1996) 193-200.

[104] Knapp R., The influence of different tree species on the plants growing beneath them, Berichte der deutschen botanischen Gesellschaft 71 (1958) 411-421.

[105] Koch A.S., Matzner E., Heterogeneity of soil and soil solution chemistry under Norway spruce (Picea abies Karst.) and European beech (Fagus sylvatica L.) as influenced by distance from the stem basis, Plant Soil 151 (1993) 227-237.

[106] Koerner W., Dupouey J.L., Dambrine E., Benoit M., Influence of past land use on the vegetation and soils of present day forest in the Vosges mountains, France, J. Ecol. 85 (1997) 351-358.

[107] Kolka R.K., Gringal D.F., Nater E.A., Forest soil mineral weathering rates, Geoderma 73 (1996) 1-21.

[108] Krapfenbauer A., Buchleitner E., Holzernte, Biomassenund Naehrstoffaustrag und Naehrstoffbilanz eines Fichtenbestandes, Centralblatt fuer das gesamte Forstwesen 98A (1981) 193-222.

[109] Kreutzer K., The impact of forest management practices on the soil acidification in established forests, Air Pollution Report 13 of the EU, Brussels, 1989, 75-90.

[110] Landmann G., Bonneau M., Bouhot-Delduc L., Fromard F., Chéret V., Dagnac J., Souchier B., Crown damage in Norway spruce and silver fir: relation to nutritional status and soil chemical characteristics in the French mountains, in: Landmann G., Bonneau M. (Eds.), Forest decline and atmospheric deposition effects in the french mountains, Springer-Verlag, Berlin, 1995, pp. 41-81.
[111] Lelong F., Dupraz C., Durand P., Didon-Lescat J.F., Effects of vegetation type on the biogeochemistry of small catchments (Mont Lozère, France), J. Hydrol. 116 (1990) 125-145.

[112] Lévy G., Premiers résultats d'étude comparée de la nappe temporaire des pseudogleys sous résineux et sous feuillus Ann. Sci. For. 26 (1969) 65-79.

[113] Leyval C., Intéractions bactéries-mycorhizes dans la rhizosphère du pin sylvestre et du hêtre: incidences sur l'exsudation racinaire et l'altération des minéraux, Thèse de Doctorat, Université de Nancy I, 1988, 263 p.

[114] Lischeid G., Prozeßorientierte hydrologische Untersuchungen am kleinen Gudenberg bei Zierenberg (Nordhessen) in verschiedenen Skalenbereichen, Berichte d. Forschungszentrums Waldökosysteme, Reihe A Bd 128, 1995.

[115] Lochmann V., Mares V., Air pollutant fallout in forest ecosystems of the Orlicke Mountains and its effect on chemical composition of precipitation, soil, and stream water and on soil development, Communicationes Instituti Forestalis Behemicae 18, Forestry and Game Management Research Institute Jiloviste-Staradny, CR, 1995.

[116] Lücke K., Schmidt W., Vegetation und Standortsverhältnisse in fichten-Buchen-Mischbeständen des Sollings, Forstarchiv. 68 (1997) 135-143.

[117] Lundström U., Öhman L.O., Dissolution of feldspars in the presence of natural organic solutes, J. Soil Sci. 58 (1990) 359-369.

[118] Lundstöm U., van Breemen N., Bain D., The podzolozation process. A review, Geoderma 94 (2000) 91-107.

[119] Lyr H., Fiedler H.J., Tranquillini W., Physiologie und Ökologie der Gehölze, Gustav Fischer Verlag Jena Stuttgart, 1992.

[120] Mardulyn P., Godden B., Amiano-Echezarreta P., Penninckx M., Gruber W., Herbauts J., Changes in humus microbiologicalactivity induced by the substitution of the natural beech forest by Norway spruce in the Belgian Ardennes, For. Ecol. Manage. 59 (1993) 15-27.

[121] Marquès R., Dynamique du fonctionnement minéral d'une plantation de Douglas (Pseudotsuga menziesii (Mirb.) Franco) dans les Monts du Beaujolais (France), Thèse de Doctorat, Université de Nancy I, 1996, 240 p.

[122] Matzner E., Ulrich B., The turnover of protons by mineralization and ion uptake in a beech (Fagus sylvatica) and a Norway spruce Ecosystem, in: Ulrich B., Pankrath J. (Eds.), Effects of accumulation of air polluants in forest ecosystems, Proceedings of a workshop, Göttingen, 1982, D. Reidel publishing company, London, 1983, pp. 93-103.

[123] Matzner E., Der Stoffumsatz zweier Waldökosysteme im Solling; Ber. des Forschungszentrums Waldökosyst. d. Univ. Göttingen, Reihe A, Bd. 41, 1988.

[124] Matzner E., Blanck K., Hartmann G., Stock R., Needle chlorosis pattern in relation to soil chemical properties in two Norway spruce (Picea abies, Karts.) forests of the german Harz mountains, in: Bucher J.B., Bucger-Wallin I. (Eds.), Air pollution and forest decline, 1989, pp. 191-201. 
[125] McClaugherty C.A., Pastor J., Aber J.D., Melillo J.M., Forest litter decomposition in relation to soil nitrogen dynamics and litter quality, Ecology 66 (1985) 266-275.

[126] Meentemeyer V., Berg B., Regional variation in rate of mass loss of Pinus sylvestris needle litter in swedish pine forests as influenced by climate and litter quality, Scand. J. For. Res. 1 (1986) 167-180.

[127] Miehlich G., Einfluß des Fichtenreinanbaus auf Grobporenverteilung, pH-Wert, Humus und Nährelementgehalte eines Lößlehm-Pseudogleys, Forstw. Cbl. 90 (1971) 301-318.

[128] Migge S., Maraun M., Scheu S., Schaefer M., The oribatid community (Acarina) of pure and mixed stands of beech $(\mathrm{Fa}$ gus sylvatica) and spruce (Picea abies) of different age, Appl. Soil Ecol. 9 (1998) 115-121.

[129] Mikola P., The effect of tree-species on the biological properties of forest soil, National Swedish Environmental Protection Board, Rapport 3017, 1985, 26 p.

[130] Miles J., The pedogenic effects of different species and vegetation types and the implications of succession, J. Soil Sci. 36 (1985) 571-584.

[131] Mitscherlich G. Wald, Wachstum und Umwelt. J.D. Sauerländer's Verlag, Frankfurt a.M, 1981.

[132] Mohamed-Ahmed M.A., Rôle du facteur édaphique dans le fonctionnement biogéochimique et l'état de santé de deux pessières vosgiennes. Effet d'un amendement calci-magnésien, Thèse de Doctorat, Université de Nancy I, 1992, 206 p.

[133] Muys B., 1995. The influence of tree species on humus quality and nutrient availability on a regional scale (Flanders, Belgium), Plant Soil 168-169, 649-660.

[134] Nielsen K.E., Ladekarl U.L., Nornberg P., Dynamic soil processes on heathland due to changes in vegetation to oak and Sitka spruce, For. Ecol. Manage. 114 (1999) 107-116.

[135] Nihlgard B., The microclimate in a beech and a spruce forest - a comparative study from Kongalund, Scania, Sweden, Botanica Notiser 122 (1969) 333-352.

[136] Nihlgard B., Precipitation, its chemical composition and effect on soil water in a beech and a spruce forest in south Sweden, Oikos 21 (1970) 208-217.

[137] Nihlgard B., Pedological influence of spruce planted on former beech forest soils in Scania, south Sweden, Oikos 22 (1971) 302-314.

[138] Nihlgard B., Plant biomass, primary production and distribution of chemical elements in a beech and a planted spruce forest in South Sweden, Oikos 23 (1972) 69-81.

[139] Noirfalise A., Vanesse R., Conséquenses de la monoculture des conifères pour la conservation des sols et pour le bilan hydrologique, A.S.B.L., Association des Espaces Verts (Ed.), 1975, $44 \mathrm{p}$.

[140] Norden U., Acid deposition and throughfall fluxes of elements as related to tree species in deciduous forests of South Sweden, Water Air Soil Pollut. 60 (1991) 209-230.

[141] Norden U., Influence of broad-leaved tree species on $\mathrm{pH}$ and organic matter content of forest topsoils in Scania, South Sweden, Scand. J. For. Res. 9 (1994) 1-8.
[142] Nykvist N., Leaching and decomposition of water-soluble organic substances from different types of leaf and needle litter, Studia Forestalia Suecica 3 (1963) 1-31.

[143] Nys C., Modifications des caractéristiques physico-chimiques d'un sol brun acide des Ardennes primaires par la monoculture d'Epicéa commun, Ann. Sci. For. 38 (1981) 237-258.

[144] Nys C., Fonctionnement du sol d'un écosystème forestier. Conséquences des enrésinements, Thèse de Doctorat, Université de Nancy I, 1987, 207 p.

[145] Nys C., Bullock P., Nys A., Micromorphological and physical properties of a soil under three different species of trees, Proceeding of the VIIth international working meeting on soil micromorphology (Paris, July 1985), 1987, pp. 459-464.

[146] Nys C., Richter C., Picard J.F., Renaud J.P., Restoration of acidic forest soils in the Ardennes and Vosges mountains using lime. Its effects on ecosystem fertility, Eurosoil conference of the British Society of Soil Science. University of Reading, UK, 4-6 September, 2000.

[147] Olsson B.A., Bengtsson J., Lundkvist H., Effects of different forest harvest intensities on the pools of exchangeable cations in coniferous forest soils, For. Ecol. Manage. 84 (1996) 135-147.

[148] Ovington J.D., Studies of the development of woodland conditions under different trees. Part I - Soil pH, J. Ecol. 41 (1953) $13-34$.

[149] Ovington J.D., Studies of the development of woodland conditions under different trees. Part II - The forest floor, J. Ecol. 42 (1954) 71-80.

[150] Ovington J.D., Studies of the development of woodland conditions under different trees. III - The ground flora, Ecology 43 (1955) 1-21.

[151] Ovington J.D., Madgwick H.A.I., Afforestation and soil reaction, J. Soil Sci. 8 (1957) 141-149.

[152] Page G., Some effects of conifer crops on soil properties, Commonwealth Forestry Review 47 (1970) 52-62.

[153] Paris F., Bonnaud P., Ranger J., Lapeyrie F., In vitro weathering of phlogopite by ectomycorrhizal fungi. I - Effect of $\mathrm{K}^{+}$and $\mathrm{Mg}^{2+}$ deficiency on phyllosilicate evolution, Plant Soil 177 (1995) 191-201.

[154] Parker G.G., Throughfall and stemflow in the forest nutrient cycle, Adv. Ecol.Res. 13 (1983) 57-133.

[155] Parmentier G., Remacle J., Production de litière et dynamisme de retour au sol des éléments minéraux par l'intermédiaire des feuilles de hêtre et des aiguilles d'épicéa en Haute Ardenne, Rev. Ecol. Biol. Sol 18 (1981) 159-177.

[156] Party J.P., Probst A., Dambrine E., Thomas A.L., Critical loads of acidity to surface waters in the Vosges Massif (NorthEast of France), Water Air Soil Pollut. 85 (1995) 2407-2412.

[157] Pasak V., Effect of tree species composition on air and soil temperatures in stands, Sborn. csl. Akad. Zemed. Ved (Lesn.) 6 (1960) 603-614.

[158] Peck A., Mayer H., Einflußvon Bestandesparametern auf die Verdunstung von Wäldern, Forstwissenschaftliches Centralblatt (1996) 1-9. 
[159] Pellisier F., Souto X.C., Allelopathy in northern temperate and boreal semi-natural woodland, Critical Reviews in Plant Sciences 18 (1999) 637-652.

[160] Perala D.A., Alban D.H., Biomass, nutrient distribution and litterfall in Populus, Pinus and Picea stands on two different soils in Minnesota, Plant Soil 64 (1982) 177-192.

[161] Peterken G.F., Game M., Historical factors affecting the number and distribution of vascular plant species in the woodlands of central Lincolnshire, J. Ecol. 72 (1984) 155-182.

[162] Pigott C.D., The influence of evergreen coniferous nurse-crops on the field layer in two woodland communities, J. Appl. Ecol. 27 (1990) 448-459.

[163] Ponge J.F., Vannier G., Arpin P., David, J.F., Caractérisation des humus et des litières par la faune du sol. Intérêt sylvicole, Rev. For. Fr. 38 (1986) 509-516.

[164] Probst A., Massabuau J.C., Probst J.L., Fritz B., Acidification des eaux de surface sous l'influence des précipitations acides: Rôle de la végétation et du substratum, conséquences pour les populations de truites. Le cas des ruisseaux des Vosges, C.R. Acad. Sci. Paris 311 (1990) 405-411.

[165] Quideau S.A., Chadwick O.A., Graham R.C., Wood H.B., Base cation biogeochemistry and weathering under oak and pine: a controlled long-term experiment, Biogeochemistry 35 (1996) 377-398.

[166] Ranger J., Nys C., Robert M., Intérêt de l'implantation de minéraux-test dans les sols, pour caractériser le fonctionnement actuel des sols, Sci. Sol 30 (1992) 193-214.

[167] Ranger J., Nys C., The effect of spruce (Picea abies Karst.) on soil development: an analytic and experimental approach, Eur. J. Soil Sci. 45 (1994) 193-204.

[168] Ranger J., Marques R., Colin-Belgrand M., Flammang N., Gelhaye D., The dynamics of biomass and nutrient accumulation in a Douglas-fir (Pseudotsuga menziesii Franco) stand studied using a chronosequence approach, For. Ecol. Manage. 72 (1995) 167-183.

[169] Ranger J., Marques R., Colin-Belgrand M., Nutrient dynamics during the development of a Douglas-fir (Pseudotsuga menziesii Mirb.) stand, Acta Oecol. 18 (1997) 73-90.

[170] Ranger J., Turpault M.P., Input-output nutrient budgets as a diagnostic tool for sustainable forest management, For. Ecol. Manage. 122 (1999) 139-154.

[171] Raulund-Rasmussen K., Vejre H., Effect of tree species and soil properties on nutrient immobilization in the forest floor, Plant Soil 168-169 (1995) 345-352.

[172] Raulund-Rasmussen K., Borggaard O.K., Hansen H.C.B., Olsson M., Effect of natural organic soil solutes on weathering rates of soil minerals, Eur. J. Soil Sci. 49 (1998) 397-406.

[173] Read R.A., Walker L.C., Influence of eastern redcedar on soil in Connecticut pine plantations, J. For. (1950) 337-339.

[174] Rehfuess K.E., Waldböden. Entwicklung, Eigenschaften und Nutzung, Verlag Paul Parey, Hamburg und Berlin, 1991.

[175] Reuss J.O., Johnson D.W., Acid deposition and the acidification of soils and waters, Springer-Verlag, New York Inc., 1986, $119 \mathrm{p}$.
[176] Roberts J., Conservative and conservative mechanisms in forest transpiration. Wald und Wasser, Prozesse im Wasserund Stoffkreislauf von Waldgebieten, Grafenau, Bayer. Wald, Tagungsbericht Bd 2, 1985, 605-614.

[177] Rodin L.E., Basilevich N.I., Production and mineral cycling in terrestrial vegetation, Fogg, Oliver, Boyd (Eds.), Edimburgh, 1967.

[178] Rothe A., Influence of tree species composition on rooting patterns, hydrology, elemental turnover and growth in a mixed spruce - beech stand in Southern Germany Höglwald, Ph.D. Thesis, University of Munich Forstliche Forschungsberichte München, Bd. 163, 1997. [in German with English summary]

[179] Rothe A., Huber C., Kreutzer K., Weis W., Deposition and soil leaching in stands of Norway spruce and European beech: results from the Höglwald research in comparison with other European case studies, Plant Soil (2000 special number, in press).

[180] Rothe A., Binkley D., Nutritional interactions in mixed species forests -A synthesis, Can. J. For. Res. (2001) in press.

[181] Rousseau P., L'évolution des forêts françaises métropolitaines d'après les statistiques forestières, Rev. For. Fr. 47 (1990) $56-65$.

[182] Saetre P., Struressson-Saetre L., Brandtberg P.O., Lundkvist H., Bergtsson J., Ground vegetation composition and heterogeneity in pure Norway spruce and mixed Norway spruce-birch stands, Can. J. For. Res. 27 (1997) 2034-2042.

[183] Saetre P., Decomposition, microbial community structure, and earthworm effects along a birch-spruce soil gradient, Ecology 79 (1998) 834-846.

[184] Saetre P., Baath E., Spatial variation and patterns of soil microbial community structure in a mixed spruce-birch stand, Soil Biol. Biochem. 32 (2000) 909-917.

[185] Schlenker D., Dieterich H., Müller S., Benecke B., Babel U., Evers F.H., Untersuchungen über die Auswirkungen des Fichtenreinanbaus auf Parabraunerden und Pseudogleye des Neckarlandes, Mitt. Ver. Forstl. Standortskde. u. Forstpflzüchtg. 19 (1969) 72-114.

[186] Scott N.A., Binkley D., Foliage litter quality and annual net mineralisation: comparison across North American forest sites, Oecologia 111 (1997) 151-159.

[187] Simmons E.A., Buckley G.P., Ground vegetation under planted mixtures of trees, in: Cannell M.G.R., Malcolm D.C., Robertson P.A. (Eds.), The ecology of mixed-species stands of trees, Special Publication 11 of the Britisch Ecological Society, Blackwell Scientific Publications, Oxford, 1992.

[188] Simoncic P., The response of the forest ecosystem to the influence of acid depositions, with emphasis on the study of nutrition conditions for spruce (Picea abies L. Karst.) and beech (Fagus sylvatica L.) in the area affected by the Sostanj thermal power plant, $\mathrm{Ph}$.D. Thesis, Ljubljana, Biotechnical Faculty, Forestry department, 1996, 155 p. [in Slovene with English summary].

[189] Skeffington R.A., Soil properties under three species of tree in southern England in relation to acid deposition in throughfall, in: Ulrich B., Pankrath J. (Eds.), Effect of accumulation of air pollutants in forest ecosystems, Reidel publishing Company, 1983, pp. 219-231. 
[190] Sohet K., Herbauts J., Gruber W., Changes caused by Norway spruce in an ochreous brown earth, assessed by the isoquartz method, J. Soil Sci. 39 (1988) 549-561.

[191] Smith W.H., Character and significance of forest tree root exudates, Ecology 57 (1976) 324-331.

[192] Son Y., Lee I.K., Soil nitrogen mineralization in adjacent stands of larch, pine and oak in central Korea, Ann. Sci. For. 54 (1997) 1-8.

[193] Son Y., Nonsymbiotic nitrogen fixation in forest ecosystems, Ecol. Res. (2000) in press.

[194] Ste-Marie C., Paré D., Soil, pH and N availability effects on net nitrification in the forest floors of a range of boreal forest stands, Soil Biol. Biochem. 31 (1999) 1579-1589.

[195] Stevens P.A., Throughfall chemistry beneath Sitka spruce of four ages in Beddgelert forest, North Wales, UK, Plant Soil 101 (1987) 291-294.

[196] Stone E.L., Effects of species on nutrient cycles and soil change, Phil. Trans R. Soc. Lond. 271B (1975) 149-162.

[197] Strobel B.W., Bernhoft I., Borgaard O.K., Low-molecular-weight aliphatic carboxylic acids in soil solutions under different vegetations determined by capillary zone electrophoresis, Plant Soil 212 (1999) 115-121.

[198] Sydes C., Grime J.P., Effect of tree leaf litter on herbaceous vegetation in deciduous woodland. I - Field investigations, J. Ecol. 69 (1981) 237-248.

[199] Sydes C., Grime J.P., Effects of tree leaf litter on herbaceous vegetation in deciduous woodland. II - An experimental investigation, J. Ecol. 69 (1981) 249-262.

[200] Tice K.R., Graham R.C., Wood H.B., Transformations of 2: 1 phyllosilicates in 41-year-old soils under oak and pine, Geoderma 70 (1996) 49-62.

[201] Tuzinsky L., Water balance in forest ecosystems of the Little Carpathians, Ekologia-CSSR 6 (1987) 23-40.

[202] Tyler G., Tree species affinity of decomposer and ectomycorrhizal macrofungi in beech (Fagus sylvatica L.), oak (Quercus Robur L.) and hornbeam (Carpinus betulus L.) forest, For. Ecol. Manage. 47 (1992) 269-284.

[203] Ulery A.L., Graham R.C., Chadwick O.A., Wood H.B., Decade-scale changes of soil carbon, nitrogen and exchangeable cations under Chaparral and Pine, Geoderma 65 (1995) 121-134.

[204] Ulrich B., Ahrens E., Ulrich., Soil chemical differences between beech and spruce sites. An example of the methods used, in: Ellenberg H. (Ed.), Ecological studies. Integrated experimental ecology, Springer Verlag, Berlin, 1971, pp. 171-196.

[205] Ulrich B., Interaction of forest canopies with atmospheric constituents: $\mathrm{SO}_{2}$, alkali and earth alkali cations and chloride, in: Ulrich B., Pankrath J. (Eds.), Effects of accumulation of air polluants in forest ecosystems, Proceedings of a workshop, Göttingen, 1982, D. Reidel publishing company, London, 1983, pp. $33-46$.
[206] Ulrich E., Lanier M., Schneider A., Dépôts atmosphériques et concentrations des solutions du sol, Rapport scientifique sur les années 1993 et 1994, ONF (Éd.), 1998, 135 p.

[207] van Breemen N., Mulder J., Driscoll C.T., Acidification and alkalinization of soils, Plant Soil 75 (1983) 283-308.

[208] van Breemen N., Lundstroem U.S., Jongmans A.G., Do plants drive podzolization via rock-eating mycorrhizal fungi?, Geoderma 94 (2000) 163-171.

[209] van Goor C.P., The impact of tree species on soil productivity, Netherlands J. Agri. Sci. 33 (1985) 133-140.

[210] Vanmechelen L., Groenemans R., van Ranst E., Forest soil condition in Europe. Results of a large-scale soil survey, Technical Report. EC, UN/ECE, Ministry of the Flemish Community, Brussels, Geneva, 1997, 259 p.

[211] Vannière B., Tables de production pour les forêts françaises, ENGREF (Éd.), $2{ }^{\mathrm{e}}$ Édition, Nancy, 1984.

[212] Vanseveren J.P., Étude comparative du microclimat dans une hêtraie, une pessière et une prairie. Bull. Soc. Roy. Bot. Belg. 108 (1975) 243-259.

[213] Vogt K.A., Grier C.C., Vogt D.J., Production, turnover and nutrient dynamics of above- and below-ground detritus of world forests, Adv. Ecol. Res. 15 (1986) 303-377.

[214] Wang Z., Fernandez I., Soil type and forest vegetation influences on forest floor nitrogen dynamics at the Bear Brook Watershed in Maine (BBWM), Env. Monit. Assess. 55 (1999) 221-234.

[215] Wedraogo F.X., Belgy G., Berthelin J., Seasonal nitrification measurements with different species of forest litter applied to granite-sand-filled lysimeters in the field, Bio. Fertil. Soils 15 (1993) 28-34.

[216] Willis K.J., Braun M., Sümegi P., Toth A., Does soil change cause vegetation change or vice versa? A temporal perspective from Hungary, Ecology 78 (1997) 740-750.

[217] Wilpert V.K., Kohler M., Zirlewagen D., Die Differenzierung des Stoffhaushalts von Waldoekosystemen durch die waldbauliche Behandlung auf einem Gneisstandort des Mittleren Schwarzwaldes, Mitt. FVA Baden-Wuerttemberg 197, 94 S, 1997.

[218] Wilson D.M, Grigal D.F., Effects of pine plantations and adjacent deciduous forests on soil calcium, Soil Sci. Soc. Am. J. 59 (1995) 1755-1761.

[219] Wittich W., Die Bodenpfleglichkeit der Buche, Forst-u. Holzwirt 27 (1972) 52-54.

[220] Wittkopf W., Wurzelintensität im Fichten-Buchen-Mischbestand im Vergleich zum Reinbestand, Diplomarbeit, Forstwissenschaftl. Fak. Univ. München, 1995.

[221] Wohlrab B., Ernstberger H., Meuser A., Sokollek V., Landschaftswasserhaushalt. Verlag Paul Parey, Hamburg und Berlin, 1992. 